ORNL/TM-2014/68

\title{
Aluminum Target Dissolution in Support of the Pu-238 Program
}

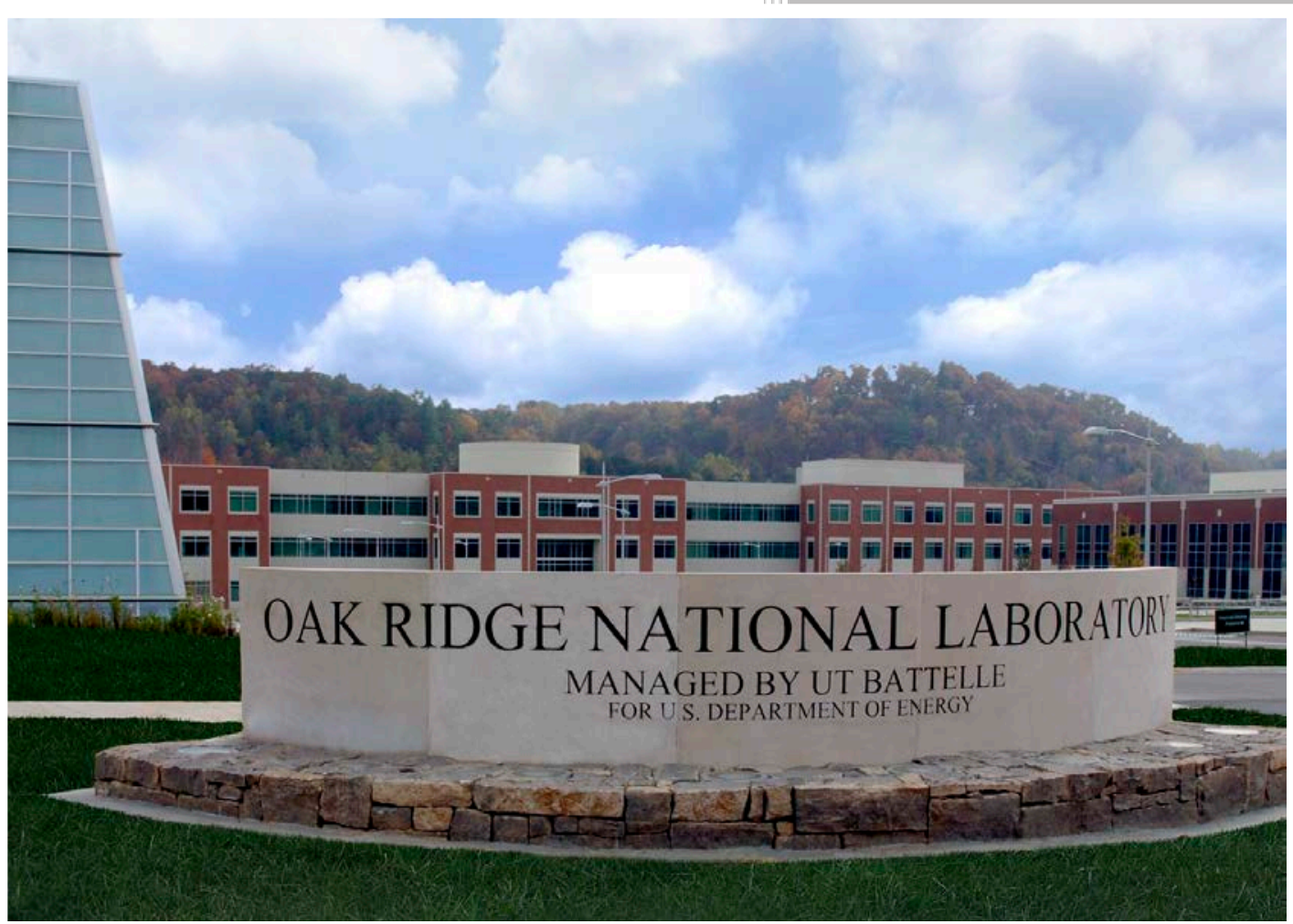

Approved for public release; distribution is unlimited.
Joanna McFarlane

Dennis Benker

David W. DePaoli

L. Kevin Felker

Catherine $\mathrm{H}$. Mattus

September 2014 


\section{DOCUMENT AVAILABILITY}

Reports produced after January 1, 1996, are generally available free via US Department of Energy (DOE) SciTech Connect.

Website http://www.osti.gov/scitech/

Reports produced before January 1, 1996, may be purchased by members of the public from the following source:

National Technical Information Service

5285 Port Royal Road

Springfield, VA 22161

Telephone 703-605-6000 (1-800-553-6847)

TDD 703-487-4639

Fax 703-605-6900

E-mail info@ntis.gov

Website http://www.ntis.gov/help/ordermethods.aspx

Reports are available to DOE employees, DOE contractors, Energy Technology Data Exchange representatives, and International Nuclear Information System representatives from the following source:

Office of Scientific and Technical Information

PO Box 62

Oak Ridge, TN 37831

Telephone 865-576-8401

Fax 865-576-5728

E-mail reports@osti.gov

Website http://www.osti.gov/contact.html

This report was prepared as an account of work sponsored by an agency of the United States Government. Neither the United States Government nor any agency thereof, nor any of their employees, makes any warranty, express or implied, or assumes any legal liability or responsibility for the accuracy, completeness, or usefulness of any information, apparatus, product, or process disclosed, or represents that its use would not infringe privately owned rights. Reference herein to any specific commercial product, process, or service by trade name, trademark, manufacturer, or otherwise, does not necessarily constitute or imply its endorsement, recommendation, or favoring by the United States Government or any agency thereof. The views and opinions of authors expressed herein do not necessarily state or reflect those of the United States Government or any agency thereof. 
Energy and Transportation Science Division

\title{
ALUMINUM TARGET DISSOLUTION IN SUPPORT OF THE Pu-238 PROGRAM
}

\author{
Joanna McFarlane \\ Dennis Benker \\ David W. DePaoli \\ L. Kevin Felker \\ Catherine H. Mattus
}

September 2014

Prepared by

OAK RIDGE NATIONAL LABORATORY

Oak Ridge, Tennessee 37831-6283

managed by

UT-BATTELLE, LLC

for the

US DEPARTMENT OF ENERGY

under contract DE-AC05-00OR22725 



\section{CONTENTS}

Page

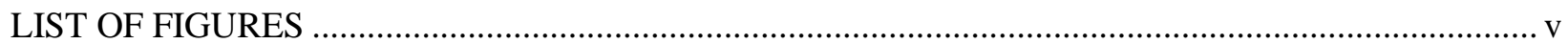

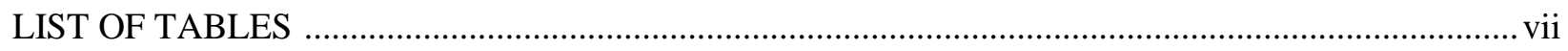

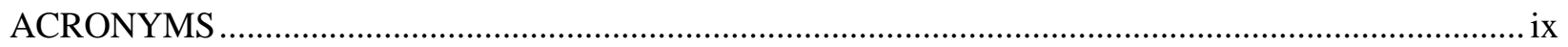

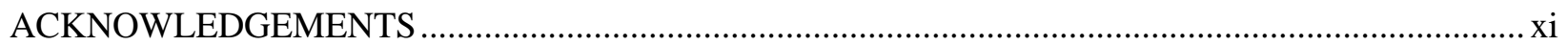

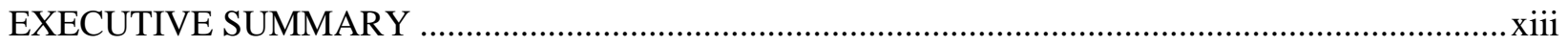

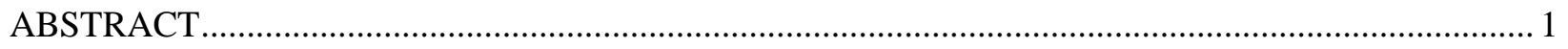

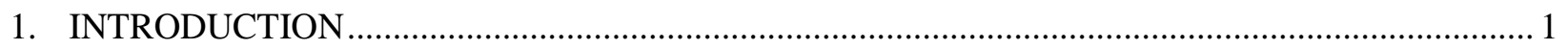

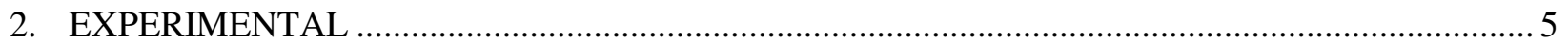

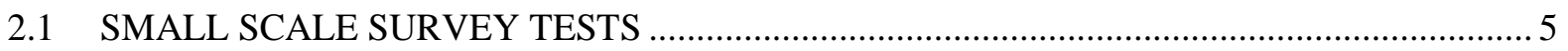

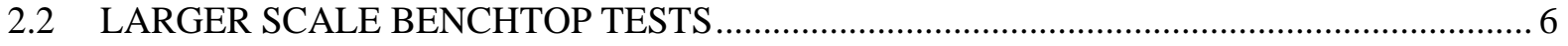

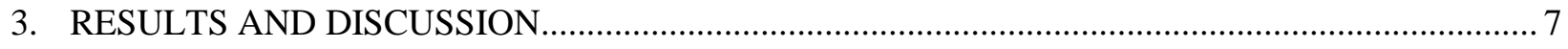

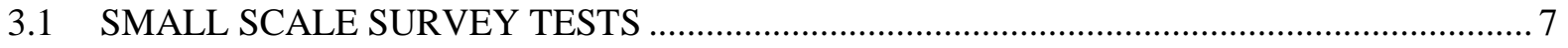

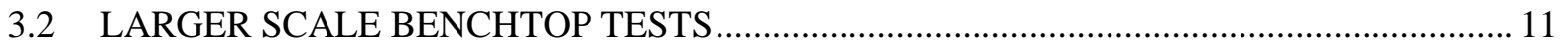

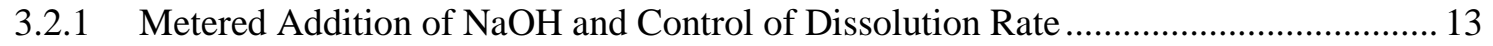

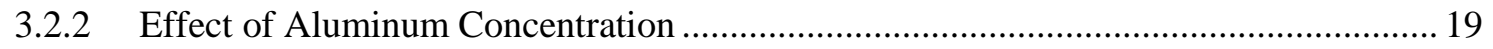

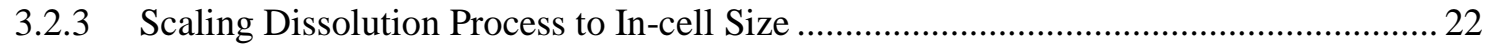

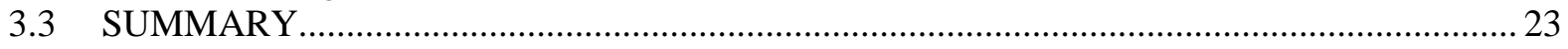

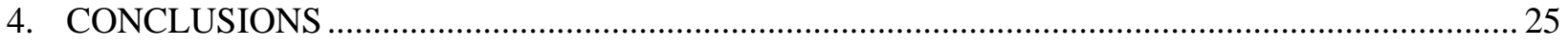

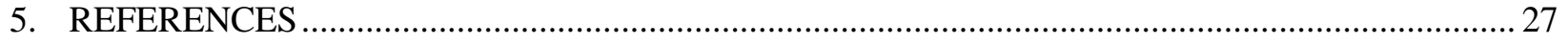





\section{LIST OF FIGURES}

Figure

Page

1 Predicted solubility of aluminum as a function of free hydroxide concentration.................... 2

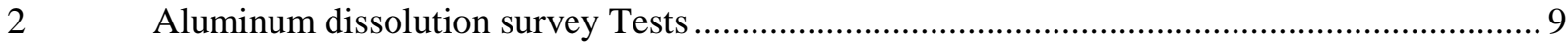

$3 \quad$ XRD of precipitates from alloy 8001 (A) and 6061 (B,C) ................................................. 4

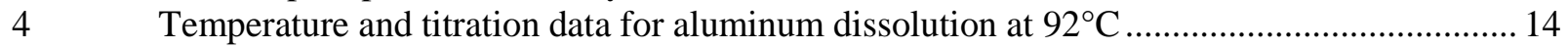

5 Temperature, dissolved \% aluminum, and flow rate of caustic as a function of time

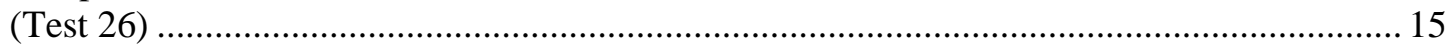

6 Temperature, dissolved \% aluminum, and flow rate of caustic as a function of time

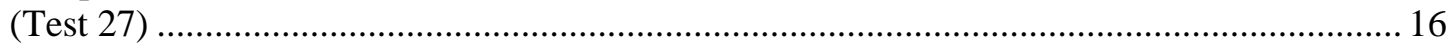

7 Temperature, dissolved \% aluminum, and flow rate of caustic as a function of time (Test 28)

8 Temperatures (solid lines) and dissolved \% aluminum as functions of time

9 Percentage of aluminum in the precipitate as a function of the initial amount introduced ..... 20

8 Mole ratios of aluminum with silicon and magnesium in the precipitate and the mass of

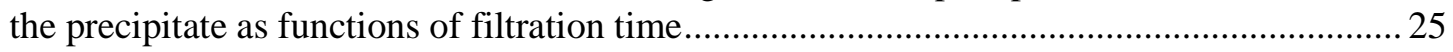

$10 \quad$ Temperature versus time for the piecewise addition of aluminum ...................................... 21

11 Titration data from grab samples obtained during a piecewise dissolution of aluminum ....... 22

12 Filtration time for each of four batches of $250 \mathrm{~mL}$ versus overall volume of filtrate............. 23

13 Solubility of aluminum as a function of hydroxide concentration ......................................... 25 



\section{LIST OF TABLES}

Table

Page

$1 \quad$ Aluminum alloy compositional specifications ............................................................ 3

2 Predicted solubilities of aluminum and silicon in contact with various aluminum alloys ......... 3

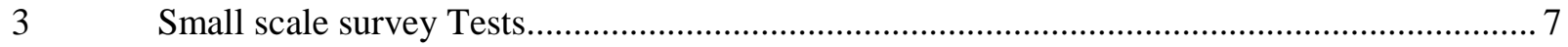

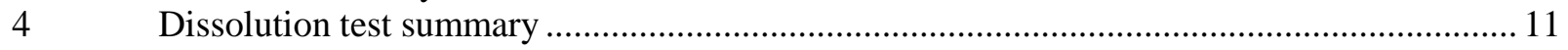

5 Results for metered and stepwise $\mathrm{NaOH}$ Tests with varied caustic concentration in the

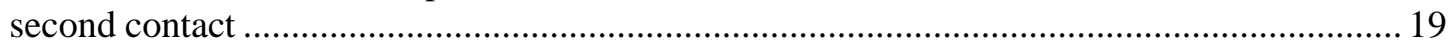





\section{ACRONYMS}

DI Deionized water

NASA National Aeronautic and Space Administration.

NIST National Institute of Standards and Technology

ORNL Oak Ridge National Laboratory

RTG radioisotope thermoelectric generator

XRD X-ray diffraction

XRF X-ray fluorescence 



\section{ACKNOWLEDGEMENTS}

This work was supported by the Pu-238 Production Project. The manuscript was authored by UTBattelle, under Contract DEAC05-00OR22725 with the US Department of Energy. The authors want to thank Dr. Michael Hu for the particle size analysis, and Dr. Roberta Meisner for the XRD analysis. 



\section{EXECUTIVE SUMMARY}

Plutonium-238 used to power radioisotope generators (RTGs) in deep space missions can be made by irradiation of neptunium-237 targets. The aluminum alloy 6061 chosen to clad the Np-237 targets was found not to dissolve completely under post-irradiation processing conditions. A pure aluminum matrix used to bind the target matrix oxide dissolved well in strong $\mathrm{NaOH}$ solution, but the silicon magnesium rich aluminum cladding formed fine precipitates, up to $10 \mathrm{wt} \%$. This residue complicated filtration and separation of the insoluble actinides from the caustic solution. This report describes Tests to understand and quantify the production of the fine solids and to suggest measures to improve filtration and separation. Although it was not possible to completely eliminate the production of solids from aluminum alloy 6061, ensuring that the dissolution takes place in an excess of $\mathrm{NaOH}$ is very important to limiting the precipitation of solids and a fast filtration. We also suggest performing a second contact with fresh $\mathrm{NaOH}$ to encourage further dissolution. Prolonged incubation at high temperatures does not improve the filterability of the solids, rather they become more gel like and filtration times become very long. 



\begin{abstract}
Selection of an aluminum alloy for target cladding affects post-irradiation target dissolution and separations. Recent tests with aluminum alloy 6061 yielded greater than expected precipitation in the caustic dissolution step, forming up to $10 \mathrm{wt} \%$ solids of aluminum hydroxides and aluminosilicates. We present a study to maximize dissolution of aluminum metal alloy, along with silicon, magnesium, and copper impurities, through control of temperature, the rate of reagent addition, and incubation time. Aluminum phase transformations have been identified as a function of time and temperature, using X-ray diffraction. Solutions have been analyzed using wet chemical methods and X-ray fluorescence. These data have been compared with published calculations of aluminum phase diagrams. Temperature logging during the transients has been investigated as a means to generate kinetic and mass transport data on the dissolution process. Approaches are given to enhance the dissolution of aluminum and aluminosilicate phases in caustic solution.
\end{abstract}

\title{
1. INTRODUCTION
}

Aluminum has long been chosen as a target encapsulation material for irradiation production of transuranic elements. ${ }^{[1]}$ Recently, aluminum alloy 6061 was selected for mixing with $\mathrm{NpO}_{2}$ precursor powder for production of Pu-238, to be used as an energy source for deep space missions. Processing of the targets after irradiation follows a procedure involving dissolution in a mixture of strong caustic and sodium nitrate as shown in overall Reaction (1), with the nitrate used to reduce the evolution of hydrogen. ${ }^{[2]}$

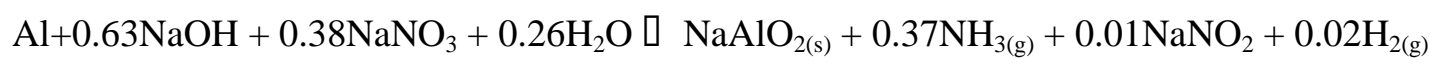

In- cell tests, however, have shown that the Al-6061 gives a larger fraction of undissolved solids than expected, leading to problems with the downstream processing. Aluminum alloys have significant differences in minor components, particularly in silicon and magnesium content, as shown in the examples given in Table 1. Hence, the objective of this work was to determine the source of the problems with the dissolution of Al-6061 and to suggest ways to ameliorate the production of solids, given the constraints of working with irradiated target materials.

Reviews of the caustic dissolution of aluminum have been reported elsewhere. ${ }^{[3,4,5]}$ The dissolution of aluminum is complex, dependent on temperature, $\mathrm{pH},{ }^{[6]}$ and $\mathrm{Eh}$, involving a number of solvated species in the aqueous phase, the most stable at high $\mathrm{pH}$ being a soluble tetrahedral compound, $\mathrm{Al}(\mathrm{OH})_{4} \cdot{ }^{-[7,8]}$ During the dissolution process, it appears that conditions can be reached under which aluminum compounds may precipitate. In the current target dissolution process this may include: dissolution when there is unsufficient caustic, and upon cooling of the solution before transfer.

Under equilibrium conditions, aluminum solubility is controlled by the solid precipitated by the saturated solution, such as gibbsite, $\alpha-\mathrm{Al}(\mathrm{OH})_{3}(\mathrm{~s}) \cdot{ }^{[8,9]}$ Fig. 1 shows solubility predictions for aluminum in sodium hydroxide solutions. The plot includes curves for gibbsite solubility at $100^{\circ} \mathrm{C}$, as predicted by Chuck Weber using SOLGASMIX, ${ }^{[10,11]}$ and at $60^{\circ} \mathrm{C}$ from a recent paper by Li et al. ${ }^{[12]}$ 


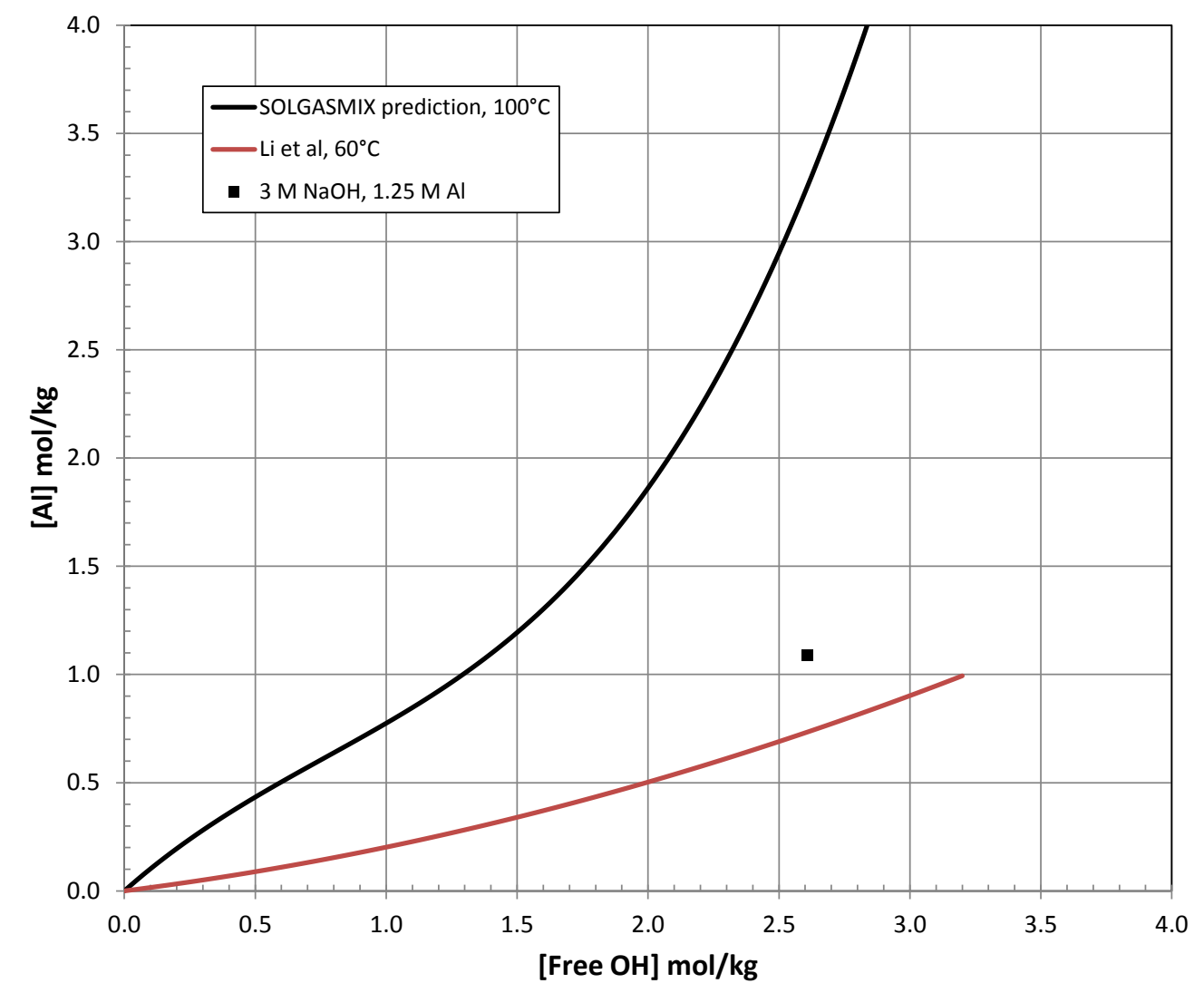

Fig. 1. Predicted solubility of aluminum as a function of free hydroxide concentration

The solution is supersaturated when the concentration point lies above the curve in this plot. To stay below the saturation line during dissolution, the rate of addition of hydroxide needs to at least balance the dissolution rate. Addition of concentrated caustic moves the point to the right (and slightly down because of increased volume), while dissolution of aluminum moves the process upward on the graph (aluminum going into solution) and to the left (hydroxide being consumed), according to Reaction (1). The historic operating guidelines call for a final aluminum concentration of up to $1.25 \mathrm{M}$, at a concentration of $3 \mathrm{M} \mathrm{NaOH}$. This point is plotted on Figure 1, using an assumed solution density of $1.15 \mathrm{~g} / \mathrm{L}^{[13]}$ to convert to molality units. It is worth noting that this point is somewhat above the predicted solubility for gibbsite at $60^{\circ} \mathrm{C}$. This is not expected to cause operational problems.

Studies have shown that solids are precipitated upon aging. ${ }^{[13]}$ However, the sodium aluminate is metastable and will remain in solution for at $100 \mathrm{~h}$ in a 1.5- 2 fold excess of caustic. The sodium aluminate will eventually convert to insoluble aluminum oxide, determined by XRD to be gibbsite, boehmite $(\mathrm{AlO}(\mathrm{OH})),{ }^{[14,15]}$, or bayerite $(\beta-\mathrm{Al}(\mathrm{OH}) 3)$, depending on the temperature and minor chemicals, ${ }^{[16]}$ and a variety of other process variables. ${ }^{[17,18,19]}$ To ensure that solids formation is not a problem, supersaturation conditions should be avoided. The curves in Fig. 1 approximate the solubility of Al during the target dissolution process, particularly during digestion and cooling. It is clear that aluminum solubility is a strong function of free hydroxide concentration and of temperature.

The rate of dissolution will also be proportional to the exposed surface are of the aluminum to the caustic, thus a coating of $\mathrm{Al}_{2} \mathrm{O}_{3}$ will slow the initial dissolution of the metal. This effect can be reduced by pretreatment of the aluminum to reduce coverage by surface impurities. 
Table 1. Aluminum alloy compositional specifications ${ }^{[20,21]}$

\begin{tabular}{lccc}
\hline Elements & Al 6061 (\%) & Al 8001 (\%) & MX8001 \\
\hline Aluminum & $95.8-98.6$ & 98.3 & 98.4 \\
Chromium & $0.040-0.35(0.25)$ & & \\
Copper & $0.15-0.40(0.25)$ & $<=0.15(260 \mathrm{ppm})$ & \\
Iron & $<=0.70$ & $0.45-0.70(0.48)$ & $(0.53)$ \\
Magnesium & $0.80-1.2(1.0)$ & & \\
Nickel & & $0.90-1.3(1.19)$ & $(0.93)$ \\
Silicon & $0.40-0.80(0.6)$ & $<=0.17(0.06)$ & $(0.003)$ \\
Titanium & $<=0.15$ & & $(0.11)$
\end{tabular}

Minor alloy components, such as silicon and magnesium, will also play a role in the dissolution chemistry, Table 2, a fact that has been demonstrated by the Tests described within. The solubilities shown in Table 2 are based on $20 \mathrm{~g}$ of aluminum, with composition determined from the alloys in Table 1 and a solution volume of $0.59 \mathrm{~L}$.

Table 2. Predicted solubilities of aluminum and silicon in contact with various aluminum alloys

\begin{tabular}{l|rrrrrrrrr}
\multicolumn{1}{c|}{ Alloy } & $\begin{array}{c}\text { Total } \\
\text { Mass, }\end{array}$ & $\begin{array}{c}\text { Total } \\
\text { Al, } \mathbf{g}\end{array}$ & $\begin{array}{c}\text { Total Si, } \\
\text { g }\end{array}$ & $\begin{array}{c}\text { moles } \\
\text { Al }\end{array}$ & $\begin{array}{c}\text { mmoles } \\
\text { Si }\end{array}$ & $\begin{array}{c}\text { volume, } \\
\text { L }\end{array}$ & [Al] $\boldsymbol{M}$ & $\begin{array}{c}\text { [Si] } \\
\mathbf{m} \boldsymbol{M}\end{array}$ & $\boldsymbol{K}_{\boldsymbol{s} \boldsymbol{p}}$ \\
\hline $6061 \mathrm{Al}$ & 20 & 19.6 & 0.12 & 0.726 & 4.2727 & 0.59 & 1.225 & 7.210 & 0.0088 \\
X8001 & 20 & 19.7 & 0.012 & 0.728 & 0.4273 & 0.59 & 1.230 & 0.721 & $8.9 \mathrm{E}-04$ \\
MX8001 & 20 & 19.7 & 0.0006 & 0.730 & 0.02136 & 0.59 & 1.231 & 0.036 & $4.4 \mathrm{E}-05$
\end{tabular}

In the final column, solubility product values are compared to a simple relationship used in previous work related to aluminosilicate formation in Savannah River Site evaporators. In that case, Savannah River National Laboratory (SRNL) developed a simple predictor for solids formation in caustic at temperature $-K_{s p}=[\mathrm{Al}] \cdot[\mathrm{Si}]$. Wilmarth and coworkers ${ }^{[22,23,24]}$ determined that aluminosilicate solids formed at $K_{s p}$ values above $3.5 \times 10^{-4} M^{2}$ to $8 \times 10^{-4} M^{2}$, and comprised gibbsite or boehmite. ${ }^{[25]}$ Subsequent Tests at ORNL indicated solids formation at $K_{s p}$ values greater than $\sim 6 \times 10^{-4} M^{2}$. ${ }^{[26]}$ Those Tests were for a somewhat different and more concentrated solution $(8.5 \mathrm{M} \mathrm{NaOH}, 1.2 \mathrm{M}$ $\mathrm{NaNO}_{3}, 1.5 \mathrm{M} \mathrm{NaNO}_{2}$ ), so the results will not match perfectly. Nonetheless, they suggest that conditions are favorable for aluminosilicate solids formation (over $1 \%$ of the initial solid mass) when dissolving $6061 \mathrm{Al}$. X8001 appears to be near the limit where solids will form, while it is unlikely that aluminosilicates will form with MX8001.

Aluminosilicate solids formed in contact with caustic solutions are very stable, progressing from amorphous to the thermodynamically more favorable crystalline cancrinite. ${ }^{[27,28]}$ The rate of these transformations depends on seed particle concentration, caustic concentration, temperature, $\mathrm{pH}$, and the presence of reactive surfaces. Thus, it is difficult to predict a priori the solubility of an alloyed aluminum in a reactive industrial process. ${ }^{[2]}$ For instance, iron impurities have been shown to increase the solubility of aluminum as a precipitate on the aluminum surface. ${ }^{[30]}$ On a microscopic level, silicon impurities have been shown to enhance the production of hydrogen because of their formation of an insoluble second phase on the aluminum alloy surface. ${ }^{[31]}$ Conversely, the precipitation of aluminosilicates may be promoted by the addition of materials such as $\mathrm{MgSO}_{4}$, in this case done to improve separation from Kraft liquors. ${ }^{[32]}$

In the work presented in this report, the goal has been to maximize aluminum solubility and solids filterability for a practical application, namely the removal and separation of aluminum alloy 6061 
target cladding. Although the system is not expected to be in equilibrium, measured aluminum concentrations have been compared with the temperature dependent gibbsite solubility curve. ${ }^{[33]}$ Trajectories on the gibbsite solubility plot indicate if supersaturated conditions are encountered, particularly under caustic-starved conditions, leading to thermodynamically favorable solids formation. The effect of solution incubation has also been investigated, or extended heating once caustic addition is complete. Temperatures were measured on-line to monitor process conditions and aluminum and hydroxide concentrations were measured by titration of grab samples.

Tests have been done under a variety of process conditions mostly within the constraints of hot cell operation, namely: keeping temperatures below boiling, minimal access to solutions during processing, and batch operation. If the predictions from Table 2 are correct, the ways to avoid aluminosilicate solids are to (i) change alloys, and (ii) to maintain the aluminum concentration in solution under $0.3 \mathrm{M}$. Only by understanding the dynamic process conditions can the solubility of aluminum be maximized. 


\section{EXPERIMENTAL}

To simulate the elevated temperatures achieved in target dissolution, the aluminum alloys were dissolved in solution at temperatures initially controlled by a thermostatted water bath, VWR or Fisher Scientific. Although active cooling is used in cell, for these tests, cooling was not used to demonstrate the effect of exothermal reactions, arguably a less conservative approach. Weighed and sectioned aluminum tubing was heated to a predetermined temperature in a $\mathrm{NaNO}_{3}$ solution $(2.1 \mathrm{M})$. The reaction was initiated by the introduction of $10 \mathrm{M} \mathrm{NaOH}$, through bulk addition or by metering over several hours. In some of the Tests, bulk additions and metering were combined. The goal was to achieve a final concentration of $1.5 \mathrm{M} \mathrm{NaNO}_{3}$ and of $3 \mathrm{M} \mathrm{NaOH}$, a chemical environment that successfully dissolves pure aluminum and is used in the hot cell procedure.

After the dissolution step, the suspensions were filtered immediately, allowed to incubate, or decanted and contacted with a second caustic solution. Precipitates were collected on a Whatman 451 11-cmdia. filter mounted on an evacuated fritted glass funnel. Filtration was started upon achieving a steady vacuum and the time was recorded. After filtration, the solids were rinsed with 5-10 mL deionized water (DI), $18 \mathrm{MV} \cdot \mathrm{cm}$, to remove soluble salts. The solids were dried at $110^{\circ} \mathrm{C}$ in a VWR vacuum oven, weighed, and sent for analysis by X-ray fluorescence (XRF) or X-ray diffraction (XRD). XRD used a Panalytical Xpert Diffractometer, CuKD radiation and X'Celerator detector. XRF spectra were taken using a Niton XL3t handheld analyzer.

Filtrates and supernatant fluids were analyzed using the Watts and Utley wet-chemical method for carbonate, free hydroxide, and aluminum. ${ }^{[34]}$ Both phenolphthalein (Ricca Lot 4207A09) and pH (VWR SP301 meter) were used to follow the progress of the titration. Chemicals used in the analysis, without further purification, included sodium tartarte dihydrate (Ricca Lot 2302670), KF (50\% w/v Ricca lot 4302A11), $\mathrm{NaOH}$ ( 0.3 M diluted from $10 \mathrm{M} \mathrm{NaOH}$ ) and $\mathrm{HCl}$ (diluted from $6 \mathrm{~N} \mathrm{HCl}$, JT Baker lot B28P05). NaOH was standardized by titration with potassium hydrogen phthalate (CEM 2913802). The uncertainty in the calculation of excess caustic was $\pm 0.3 \mathrm{~m}$ because the results were derived from three independent titrations. The uncertainty in the aluminum concentration was $\pm 0.2 \mathrm{~m}$.

The aluminum alloy used in the Tests was usually 6061, but an 8001 alloy was used for one of the tests. The alloy was cleaned in methanol. Reagents $\mathrm{NaOH}$ (10 M, Fisher lots 127726 and 132910) and $\mathrm{NaNO}_{3}$ (JT Baker Lot 25078) were used without purification. Degassed DI water was used for all of the solution preparation and analyses.

\subsection{SMALL SCALE SURVEY TESTS}

Small scale tests $(<50 \mathrm{~mL}$ ) were used to quickly survey process conditions, using up to $1.3 \mathrm{~g}$ aluminum and caustic solution held in a $50 \mathrm{~mL}$ centrifuge vial. Multiple vials could be heated at the same time, allowing multiplexed testing for varying aluminum or caustic concentrations under the same process conditions. All of the small scale tests were performed in batch, most with a solution of $3 \mathrm{M} \mathrm{NaOH}, 1.5 \mathrm{M} \mathrm{NaNO}_{3}$, with dissolutions taking place at $100^{\circ} \mathrm{C}$ and an incubation at $60^{\circ} \mathrm{C}$ before filtration, unless otherwise noted. 


\subsection{LARGER SCALE BENCHTOP TESTS}

Dissolution testing was carried out in $0.5 \mathrm{~L}$ Teflon vessels that were heated in the thermostatted water baths, using several grams of aluminum to allow sufficient solid for post-test analysis by XRD and XRF. Sodium hydroxide solution was metered into Teflon vessels through small-dia. Teflon tubes, connected to a 4-channel peristaltic pump (Thermo Scientific- Manostat Carter Cassette Pump). Pump flow rates were calibrated gravimetrically and ranged from 0.05 to $0.46 \mathrm{~mL} \cdot \mathrm{min}^{-1}$. Besides the metering of caustic, tests were also carried out with the aluminum added piecewise to full strength $\mathrm{NaOH}+\mathrm{NaNO}_{3}$, to observe the control of reaction rate by limiting the availability of aluminum.

After dissolution was finished, the samples were often incubated under predetermined conditions of temperature, sometimes with fresh caustic being added. If a sample was to be contacted with fresh caustic the supernatant was first decanted, often requiring centrifugation (1300 rpm for 2-3 min) to settle the light sediment.

In some of the larger scale tests, temperatures in the reaction vessels were measured using a custom built 4-channel Arduino-based controller for Type-K thermocouples, and a single channel National Institute of Standards and Technology (NIST) traceable T-SPER Scientific instrument (800008). Calibration of the thermocouples was checked with the ice point of water. The accuracy of the temperature measurement was better than $\pm 1^{\circ} \mathrm{C}$; the uncertainty mainly arising from the time lag for the heat to be transferred through the protective sheath around the temperature sensor. 


\section{RESULTS AND DISCUSSION}

\subsection{SMALL SCALE SURVEY TESTS}

Preliminary Tests were conducted to test the dissolution of aluminum 6061 pieces, reproducing the $\mathrm{NaNO}_{3}$ and $\mathrm{NaOH}$ concentrations and heating conditions encountered in cell.

Table 3 gives summarizes the tests conducted with approximately $1 \mathrm{~g}$ aluminum or less. Photographs showing the appearance of the precipitates in various stages are given in Fig. 2. The first test investigated both the 8001 and 6061 alloys in the form of tubes and polished rods. The second test increased the amount of caustic in the form of solid $\mathrm{NaOH}$ pellets added to the solution to investigate if this could push the system towards complete dissolution. The third and fourth tests more thoroughly investigated the effect of caustic concentration on the amount and filterability of the precipitate. In Test 5 , the caustic was added to the vessel in $0.5 \mathrm{~mL}$ aliquots, better simulating the conditions for in-cell processing. Test 6 demonstrated filterability and solids formation for a variety of incubation times.

Table 3. Small scale survey Tests

\begin{tabular}{|c|c|c|c|c|}
\hline Test \# & Inputs & $\begin{array}{l}\text { Dissolution } \\
\text { conditions }\end{array}$ & $\begin{array}{l}\text { Incubation and } \\
\text { filtration }\end{array}$ & Notes \\
\hline 1 & $\begin{array}{l}0.98-1.21 \mathrm{~g} \mathrm{Al} \text { alloy } \\
8001 \text { and } 6061 \\
29-38 \mathrm{~mL} \\
3 \mathrm{M} \mathrm{NaOH}, \\
1.5 \mathrm{M} \mathrm{NaNO}_{3}\end{array}$ & $\begin{array}{l}75-100^{\circ} \mathrm{C} \text { stepwise, } \\
15 \text { min at each } 5^{\circ} \mathrm{C} \\
\text { increment, } 8 \mathrm{~min} \\
\text { from } 95-100^{\circ} \mathrm{C}, 37 \\
\text { min at } 100^{\circ} \mathrm{C} \text {, for } \\
120 \text { min total } \\
60^{\circ} \mathrm{C} \text { for } 19 \text { min }\end{array}$ & $\begin{array}{l}\text { centrifuged, decanted } \\
\text { and held solutions at } \\
60^{\circ} \mathrm{C} \text { overnight } \\
\text { Solids from decanted } \\
\text { solutions dried, } \\
\text { wieghed and } \\
\text { analyzed by XRD } \\
(23 \text { wt\% for } 8001 \text {, } \\
32-45 \text { wt\% for } 6061)\end{array}$ & $\begin{array}{l}8001 \text { alloy reacted } \\
\text { more quickly } \\
\text { tubes reacted more } \\
\text { quickly than rods } \\
\text { solids initially } \\
\text { black and grey } \\
\text { powder } \\
\text { fine brown } \\
\text { precipitate formed } \\
\text { overnight }\end{array}$ \\
\hline 2 & $\begin{array}{l}1.35-1.38 \mathrm{~g} \mathrm{Al} \text { alloy } \\
6061 \\
40 \pm 0.5 \mathrm{~mL} \\
3 \mathrm{M} \mathrm{NaOH}, \\
1.5 \mathrm{M} \mathrm{NaNO}_{3}\end{array}$ & $\begin{array}{l}70-100^{\circ} \mathrm{C} \text { stepwise, } \\
15 \text { min at each } 5^{\circ} \mathrm{C} \\
\text { increment, } 40 \text { min at } \\
100^{\circ} \mathrm{C} \\
0,1.61 \text { and } 3.26 \mathrm{~g} \\
\text { solid } \mathrm{NaOH} \text { added at } \\
138 \text { min and tubes } \\
\text { held at } 100^{\circ} \mathrm{C} \text { for } 5 \mathrm{~h}\end{array}$ & $\begin{array}{l}\text { Samples held at } \\
60^{\circ} \mathrm{C} \text { overnight } \\
\text { Samples centrifuged } \\
\text { and supernatant } \\
\text { decanted. Solids } \\
\text { dried and weighed. }\end{array}$ & $\begin{array}{l}\text { Reaction initiated } \\
\text { in } 30 \text { s, but took } \\
\text { about } 6 \text { min for } \\
\text { vigorous reaction } \\
\text { to occur } \\
\text { Added NaOH did } \\
\text { not reduce the } \\
\text { amount of solids, } \\
\text { but did make the } \\
\text { precipitate a lighter } \\
\text { brown and settled } \\
\text { more slowly }\end{array}$ \\
\hline 3 & $\begin{array}{l}\text { 1.24-1.34 g Al alloy } \\
6061 \\
37-40 \mathrm{~mL} \text { solution, } \\
1.5 \mathrm{M} \mathrm{NaNO}_{3} \\
4,5,6 \mathrm{M} \mathrm{NaOH}\end{array}$ & $\begin{array}{l}60^{\circ} \mathrm{C}(25 \mathrm{~min}) \\
70^{\circ} \mathrm{C}(10 \mathrm{~min}) \\
80^{\circ} \mathrm{C}(25 \mathrm{~min}) \\
90^{\circ} \mathrm{C}(25 \mathrm{~min}) \\
100^{\circ} \mathrm{C}(95 \mathrm{~min})\end{array}$ & $\begin{array}{l}\text { Solids filtered after } \\
5 \mathrm{~d} \text { at } 20^{\circ} \mathrm{C} \\
8.0 \pm 0.4 \text { wt. } \%\end{array}$ & $\begin{array}{l}\text { large variation in } \\
\text { filtration time, } 10 \text {, } \\
20 \text { and } 2.5 \mathrm{~min}\end{array}$ \\
\hline
\end{tabular}




\begin{tabular}{|c|c|c|c|c|}
\hline Test \# & Inputs & $\begin{array}{l}\text { Dissolution } \\
\text { conditions }\end{array}$ & $\begin{array}{l}\text { Incubation and } \\
\text { filtration }\end{array}$ & Notes \\
\hline 4 & $\begin{array}{l}\text { 1.1-1.2 g Al alloy } \\
8001 \\
33-37 \mathrm{~mL} \text { solution } \\
4,5,2 \mathrm{x} 6 \text {, and } 10 \mathrm{M} \\
\mathrm{NaOH} \\
1.5 \mathrm{M} \mathrm{NaNO} \\
\text { except for } 6 \mathrm{M} \text { and } \\
10 \mathrm{M} \text { solutions (one } \\
\text { each) with no } \\
\text { nitrate }\end{array}$ & $\begin{array}{l}60^{\circ} \mathrm{C}(15 \mathrm{~min}) \\
65^{\circ} \mathrm{C}(14 \mathrm{~min}) \\
70^{\circ} \mathrm{C}(16 \mathrm{~min}) \\
80^{\circ} \mathrm{C}(22 \mathrm{~min}) \\
90^{\circ} \mathrm{C}(13 \mathrm{~min}) \\
90-100^{\circ} \mathrm{C}(13 \mathrm{~min}) \\
100^{\circ} \mathrm{C}(110 \mathrm{~min}) \\
10 \mathrm{M} \mathrm{NaOH} \text { left to } \\
\text { sit overnight }\end{array}$ & $\begin{array}{l}\text { Solids filtered after } \\
2 \mathrm{~d} \text { at } 20^{\circ} \mathrm{C} \\
8 \pm 2 \mathrm{wt} \%\end{array}$ & $\begin{array}{l}\text { 17-59s filtration } \\
\text { time }\end{array}$ \\
\hline 5 & $\begin{array}{l}1.2 \mathrm{~g} 8001 \text { alloy } \\
1.0-1.36061 \text { alloy } \\
20-25 \mathrm{~mL} \\
1.5 \mathrm{M} \mathrm{NaNO}_{3} \\
9-11 \mathrm{~mL} 10 \mathrm{M} \\
\mathrm{NaOH}(0.5 \mathrm{~mL} \\
\text { aliquots added } \\
\text { every } 10 \text { min, } \\
\text { remainder at } 170 \\
\text { min) }\end{array}$ & $\begin{array}{l}\text { During the caustic } \\
\text { addition, the bath } \\
\text { temp was held at } \\
92^{\circ} \mathrm{C} \text {. After the } \\
\text { addition, it was } \\
\text { raised to } 100^{\circ} \mathrm{C} \text { for } \\
30 \text { min, and then } \\
\text { dropped to } 60^{\circ} \mathrm{C} \text { for } \\
40 \text { min }\end{array}$ & $\begin{array}{l}\text { Solids filtered at } \\
60^{\circ} \mathrm{C} \\
10 \mathrm{wt} \% \text { solids from } \\
8001 \text { (brown gel) } \\
8 \mathrm{wt} \% \text { solids from } \\
6061 \text { (black) }\end{array}$ & $\begin{array}{l}\text { Filtration time } \\
\text { between } 18-31 \mathrm{~s}\end{array}$ \\
\hline 6 & $\begin{array}{l}1.17 \pm 0.06 \mathrm{~g} \text { alloy } \\
8001 \\
1.26 \pm 0.08 \mathrm{~g} \text { alloy } \\
6061 \\
1.5 \mathrm{M} \mathrm{NaNO}_{3} \\
3 \mathrm{M} \mathrm{NaOH} \\
\text { two samples had } \\
\text { increased } \mathrm{NaOH} \\
(3.6-6.2 \mathrm{M} \mathrm{NaOH})\end{array}$ & $\begin{array}{l}75-85^{\circ} \mathrm{C} \text { stepwise } \\
\left(15 \text { min per } 5^{\circ} \mathrm{C}\right) \\
88^{\circ} \mathrm{C} \text { for } 1.5 \mathrm{~h} \\
88-98^{\circ} \mathrm{C} \text { over } 30 \text { min } \\
60^{\circ} \mathrm{C} \text { for } 15 \mathrm{~min} \\
60^{\circ} \mathrm{C} \text { overnight } \\
100^{\circ} \mathrm{C} \text { for } 4 \mathrm{~h} \\
\text { Added caustic to } 4 \\
\text { samples } \\
60^{\circ} \mathrm{C} \text { for } 15 \text { min }\end{array}$ & $\begin{array}{l}2 \text { samples of each } \\
\text { alloy filtered after } \\
\text { first } 60^{\circ} \mathrm{C} \text { period } \\
1 \text { sample of each } \\
\text { alloy filtered after } \\
\text { second } 60^{\circ} \mathrm{C} \text { period } \\
3 \text { samples of each } \\
\text { alloy filtered after } \\
\text { third } 60^{\circ} \mathrm{C} \text { period }\end{array}$ & $\begin{array}{l}\text { All filtration times } \\
\text { less than } 1 \text { min, } \\
\text { except for } 3.5 \text { min } \\
\text { for } 6061 \text { that was } \\
\text { run through full } \\
\text { incubation cycle }\end{array}$ \\
\hline
\end{tabular}

All of the dissolution tests appeared to give precipitate, no matter which alloy, the concentration of caustic and how it was introduced, or the presence of nitrate. The color of the precipitate was brown and gel-like in the case of the 6061 alloy (Fig. 2C) as opposed to a black solid from the 8001 alloy (Fig. 2D). This is also apparent in Fig. 2F.

Depending on dissolution conditions, samples of 8001 alloy gave less solid precipitate than the 6061 alloy. However, the most significant difference between the two alloys was the filtration time. In comparing Tests 3 and 4, the filtration time differed by up to a factor of 30 between the two alloys at $5 \mathrm{M} \mathrm{NaOH}$, even though the amount of precipitate was not significantly different. 


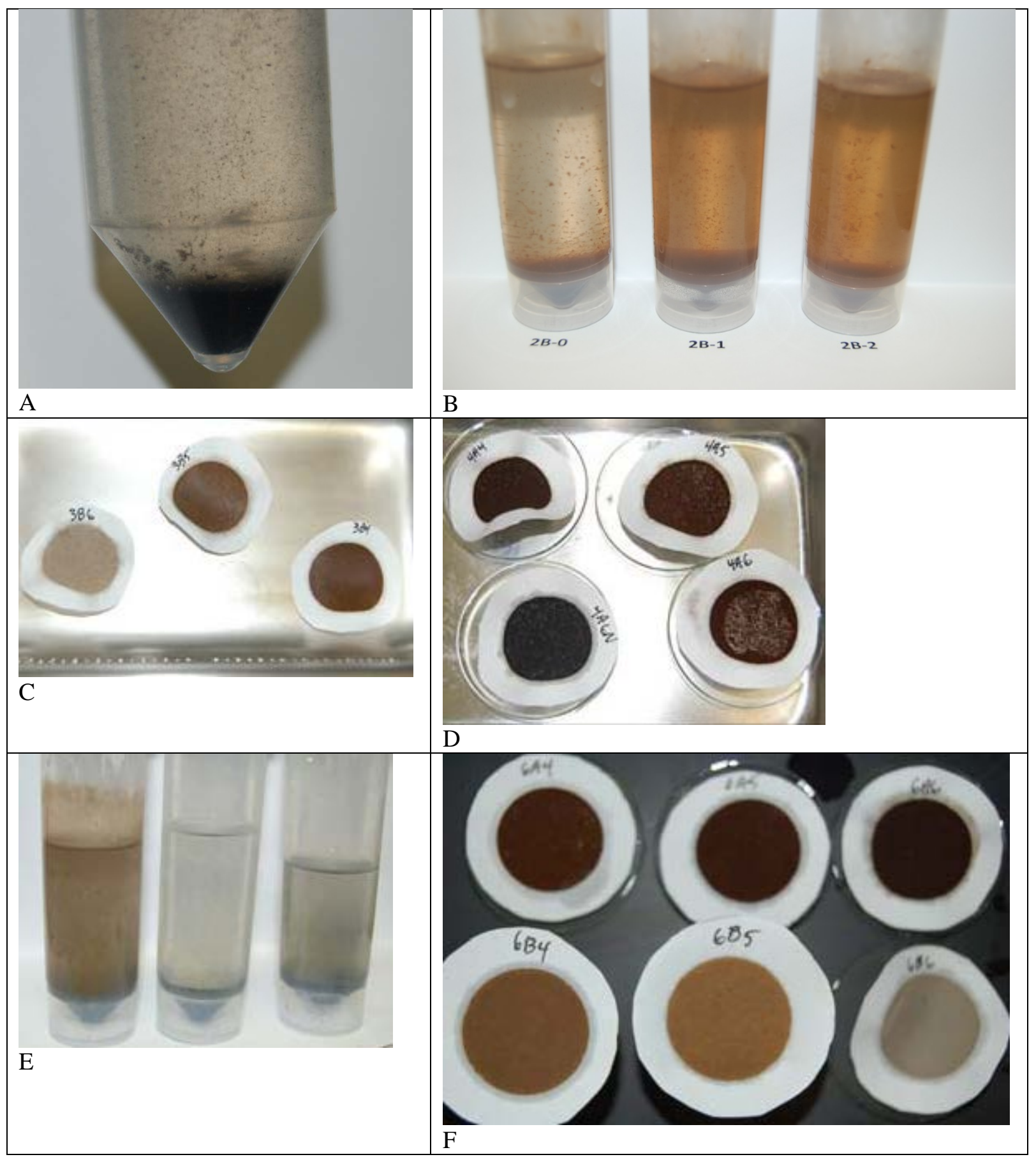

Fig 2. Aluminum dissolution survey Tests. A: Fine granular precipitate from Test 1 before an overnight incubation. B: In Test 2, the precipitate becomes progressively slower to settle with caustic added in the incubation stage, from 2B-0 (no added caustic) to 2B-2 (1.72M). C and D: Precipitates collected from Tests 3 and 4 respectively. E: Solids from alloy 8001 (left) and alloy 6061 (right) in Test 5. F: Test 6 precipitates from 8001 and 6061 alloys, top and bottom samples respectively.

Over all the tests, about 4-45 wt.\% of the initial mass of the aluminum alloy was precipitated - with the larger amounts forming after a long incubation time. In some tests hot freshly prepared precipitate was collected within seconds from both dissolved alloys; however, if the precipitate was allowed to "ripen” overnight at $60^{\circ} \mathrm{C}$, the precipitate from the 8001 alloy was filtered more readily than that from 
the 6061 alloy. Test 6 probed this effect systematically, with about 4 wt.\% solids after a rapid dissolution and filter; about 5 wt.\% solids after a $60^{\circ} \mathrm{C}$ overnight incubation; and 6 wt.\% solids following digestions at 60,100 and then $60^{\circ} \mathrm{C}$.

Although nitrate is necessary to reduce hydrogen production, the precipitation tests without nitrate produced a much more filterable solid, black and flaky, rather than brown and gelatinous. Nitrate also appeared to increase filtration time, by a factor of 3.5 in the case of alloy 8001 .

The filtration time was found to be dependent on the concentration of caustic, which was varied from 3-6 M in the preliminary Test, with higher concentrations of caustic causing longer filtration times.

Although the amounts of sample were small, an XRD analysis was done on some of the collected solids. The results for the precipitates are similar for all the cases examined (both alloys of aluminum), with aluminosilicate phases in each of the samples, Fig. 3. However, the amount of aluminosilicate is very low (2-3\%) of the solids. The majority of the collected solid comprises sodium salts, nitrates and carbonates, which agrees with XRD analyses of solids made in the hot cells (private communication Jared Johnson, May 24, 2013). The latter likely arises from reaction of $\mathrm{NaOH}$ with $\mathrm{CO}_{2}$ in the atmosphere when drying. Although hydroxycancrinite was matched in the library, dawsonite, $\mathrm{NaAl}(\mathrm{OH})_{2} \mathrm{CO}_{3}$ has been identified in other high carbonate aluminum sludges, ${ }^{[35]}$ and cannot be ruled out. In subsequent Tests, all solids were dried in a vacuum oven.

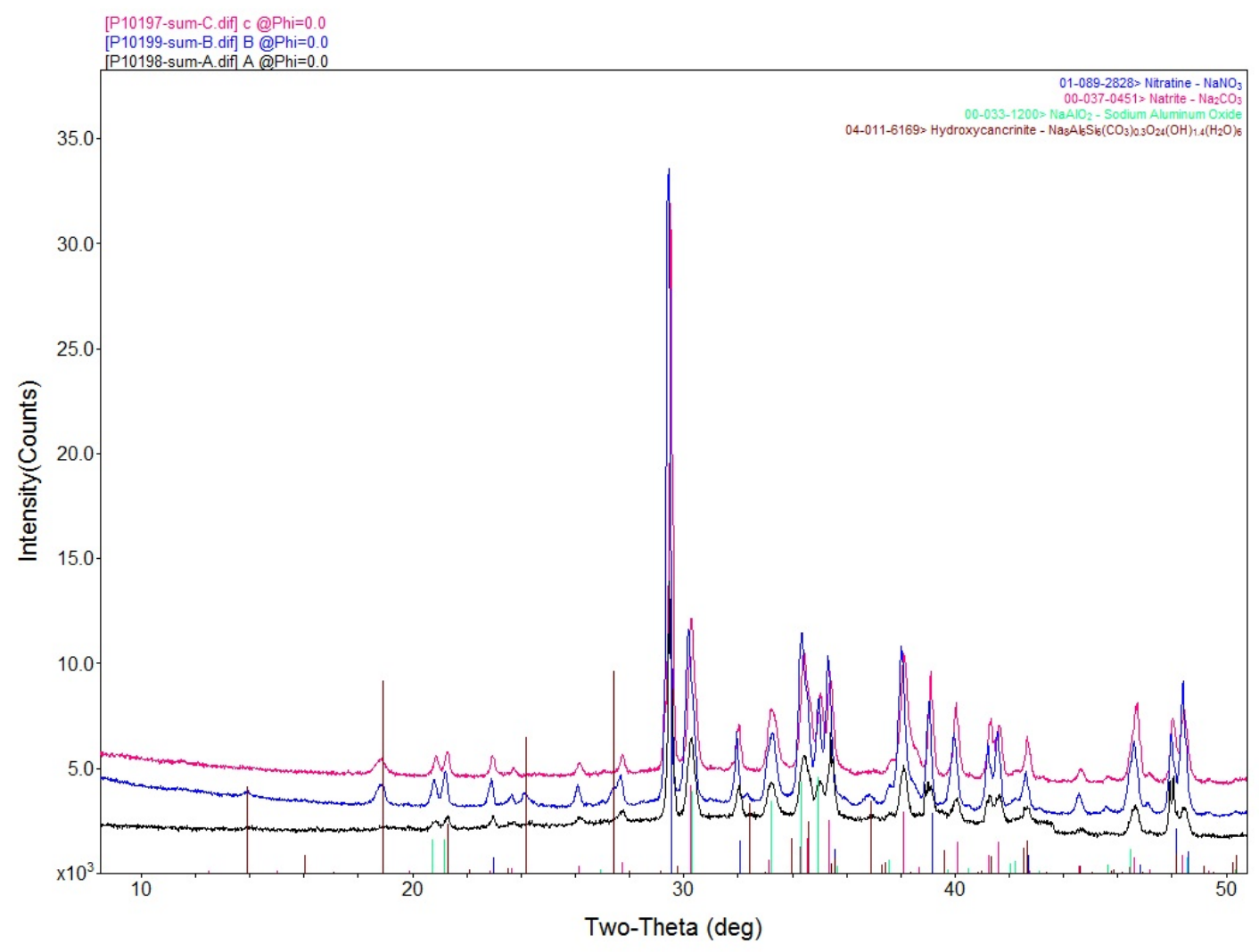

Fig. 3. XRD of precipitates from dissolved Al 8001 (A) and Al 6061 (B, C) with library identification of the main phases. 
The small-scale tests showed that the dissolution of aluminum depends on a number of variables, including the alloying elements and minor components, temperature, caustic concentration, nitrate concentration, and incubation time and temperature. These tests established the set of independent variables to be investigated in the larger scale benchtop tests.

\subsection{LARGER SCALE BENCHTOP TESTS}

Tests of aluminum dissolution were run to evaluate which conditions gave the lowest amount of solids and the best filterability of the solid that did form, while maintaining control of reaction conditions. Results from the dissolution tests are given in Table 4.

Table 4. Dissolution test summary

\begin{tabular}{|c|c|c|c|}
\hline $\begin{array}{l}\text { Dissolution Conditions } \\
\text { unless specified: } \\
3 \mathrm{M} \mathrm{NaOH}, \\
1.5 \mathrm{M} \mathrm{NaNO}_{3}\end{array}$ & Incubation Conditions & $\begin{array}{l}\text { Solids production and } \\
\text { filtration }\end{array}$ & Observations \\
\hline $\begin{array}{l}92^{\circ} \mathrm{C}, \\
\text { metered caustic over } 2 \mathrm{~h}\end{array}$ & $\begin{array}{l}97(1 \mathrm{~h}), 60^{\circ} \mathrm{C}(0.3-7 \mathrm{~h}) \\
\text { one overnight }\left(100^{\circ} \mathrm{C}\right)\end{array}$ & $\begin{array}{l}6-11 \mathrm{wt} \% \\
11-31 \mathrm{~min} \text { to filter }\end{array}$ & $\begin{array}{l}\text { dark brown solids } \\
\text { filtrate greenish at long } \\
\text { times (Test } 7 \text { ) }\end{array}$ \\
\hline $\begin{array}{l}92^{\circ} \mathrm{C}, 8001 \text { alloy } \\
\text { metered caustic over } 18 \mathrm{~h}\end{array}$ & $\begin{array}{l}95^{\circ} \mathrm{C} \text { for } 0.5 \mathrm{~h} \text {, } \\
60^{\circ} \mathrm{C} \text { and } 95^{\circ} \mathrm{C}, 0.6 \mathrm{~h} \text { up } \\
\text { to overnight }\end{array}$ & $\begin{array}{l}4 \% \text { (overnight at } 95) \\
20 \%(15 \text { min at } 60) \\
\text { short times }-2 \text { min } \\
\text { long times }-9 \text { to } 10 \text { min }\end{array}$ & $\begin{array}{l}\text { filter times often inverse } \\
\text { to amt solids (Test 9) }\end{array}$ \\
\hline $\begin{array}{l}92^{\circ} \mathrm{C} \text {, } \\
\text { metered caustic over } 30 \mathrm{~h}\end{array}$ & $\begin{array}{l}60 \text { and } 92^{\circ} \mathrm{C} \text { overnight } \\
\text { filtration at } 60^{\circ} \mathrm{C}\end{array}$ & $\begin{array}{l}7-16 \mathrm{wt} \% \\
5-8 \text { min to filter (longest } \\
\text { time with lowest amt } \\
\mathrm{ppt} / \text { long at } 60 \mathrm{C} \text { ) }\end{array}$ & $\begin{array}{l}\text { solids dark brown and } \\
\text { husks } \\
\text { hygroscopic (Test 10) }\end{array}$ \\
\hline $\begin{array}{l}92^{\circ} \mathrm{C}, \\
\text { metered caustic over } 22 \mathrm{~h}\end{array}$ & $\begin{array}{l}1 \mathrm{~h} \text { at } 99^{\circ} \mathrm{C} \\
60^{\circ} \mathrm{C} \text {-comparison } 4 \mathrm{~h} \text { and } \\
\text { very long incubation ( } 3 \\
\text { d) }\end{array}$ & $\begin{array}{l}9-11 \text { wt. } \% \\
3-7 \text { min to filter }\end{array}$ & $\begin{array}{l}\text { conversion of dark brown } \\
\text { to lighter colored solids, } \\
\text { hydroscopic } \\
\text { (Test 11) }\end{array}$ \\
\hline $\begin{array}{l}92^{\circ} \mathrm{C}, \mathrm{Half}[\mathrm{Al}] \\
\text { metered caustic over } 15 \text { - } \\
19 \mathrm{~h}\end{array}$ & $\begin{array}{l}97+{ }^{\circ} \mathrm{C} \text { for } 0.5 \mathrm{~h} \\
60^{\circ} \mathrm{C} \text { for } 4-21 \mathrm{~h}\end{array}$ & $\begin{array}{l}\text { up to } 11 \text { wt } \% \\
\text { dark brown \& } \\
\text { hygroscopic } \\
\text { 2-4 min to filter }\end{array}$ & (Test 12) \\
\hline $\begin{array}{l}92^{\circ} \mathrm{C}, \\
\text { metered caustic over } 20 \mathrm{~h}\end{array}$ & $\begin{array}{l}95^{\circ}{ }^{\circ} \mathrm{C} \text { for } 0.5 \mathrm{~h} \\
\text { long incubations at } 60 \\
\text { and } 95^{\circ} \mathrm{C}\end{array}$ & $\begin{array}{l}\text { up to } 14 \text { wt } \% \\
7-54 \text { min to filter }\end{array}$ & $\begin{array}{l}\text { brown, husks, } \\
\text { (Tests } 8 \text { and 13) }\end{array}$ \\
\hline $\begin{array}{l}70^{\circ} \mathrm{C} \text {, small batches } \\
\text { low amounts } \mathrm{Al}\end{array}$ & $\begin{array}{l}99 \text { for } 9 \mathrm{~h} \\
60^{\circ} \mathrm{C} \text { overnight }\end{array}$ & $\begin{array}{l}4-6 \% \\
\text { fast filtration }\end{array}$ & (Test 14) \\
\hline $\begin{array}{l}20^{\circ} \mathrm{C} \text {, batch } \\
\text { Half [Al] for Test } 16\end{array}$ & $\begin{array}{l}60-98^{\circ} \mathrm{C} \text { for } 24 \mathrm{~h} \text { after } \\
\text { decanting from black } \\
\text { solids (32 wt.\%) }\end{array}$ & $\begin{array}{l}<2 \% \text { on filter paper } \\
\text { (amount not dependent on } \\
\text { Al concentration) } \\
\text { less than a } 0.5 \text { min to } \\
\text { filter }\end{array}$ & $\begin{array}{l}100 \% \mathrm{Al} \text { at } 0.7 \mathrm{M} \text {, } \\
77 \% \mathrm{Al} \text { at } 1.34 \mathrm{M} \\
\text { dissolved after } 24 \mathrm{~h} \\
\text { fine brown solids ppt } \\
\text { when filtrate cooled } \\
\text { (Tests } 15 \text { and } 16 \text { ) }\end{array}$ \\
\hline $\begin{array}{l}20^{\circ} \mathrm{C} \text {, batch } \\
\text { Half [Al] }\end{array}$ & $\begin{array}{l}22 \mathrm{~h} \text { with no heating } \\
\mathrm{T} \text { increase to } 22^{\circ} \mathrm{C}\end{array}$ & $\begin{array}{l}\text { 35wt\% solids } \\
\text { black }\end{array}$ & $\begin{array}{l}\text { with T logging } \\
\text { not all dissolved (Test 17) }\end{array}$ \\
\hline
\end{tabular}




\begin{tabular}{|c|c|c|c|}
\hline $\begin{array}{l}\text { Dissolution Conditions } \\
\text { unless specified: } \\
3 \mathrm{M} \mathrm{NaOH} \text {, } \\
1.5 \mathrm{M} \mathrm{NaNO}_{3}\end{array}$ & Incubation Conditions & $\begin{array}{l}\text { Solids production and } \\
\text { filtration }\end{array}$ & Observations \\
\hline $92^{\circ} \mathrm{C}$ batch & $\begin{array}{l}\text { dissolution overnight, } \\
\text { overnight at } 92^{\circ} \mathrm{C} \text { in fresh } \\
3,5,7,5,10 \mathrm{M} \mathrm{NaOH}\end{array}$ & $\begin{array}{l}\text { 13s for } 3 \mathrm{M} \text {, much longer } \\
\text { for other [caustic] } \\
1.2-4.8 \% \text { solids }\end{array}$ & $\begin{array}{l}\text { testing incubation with } \\
\text { fresh caustic, } \\
\text { longer filtration with } \\
\text { gelatinous ppts. } \\
\text { (Test 18) }\end{array}$ \\
\hline $60^{\circ} \mathrm{C}$ batch & $\begin{array}{l}\text { dissolution overnight, } \\
100 \mathrm{~mL} 3 \mathrm{M} \mathrm{NaOH} \text { in } \\
\text { oven } 90^{\circ} \mathrm{C} \text { for } 2.5 \mathrm{~h}\end{array}$ & $\begin{array}{l}2 \% \text { solids, brown } \\
25 \text { min filtration }\end{array}$ & $\begin{array}{l}\text { temperature trace, } \\
\text { (Test 19) }\end{array}$ \\
\hline $\begin{array}{l}60^{\circ} \mathrm{C} \\
\mathrm{Al} \text { piecewise addition }\end{array}$ & $\begin{array}{l}\text { overnight-bath went dry } \\
3 \mathrm{M} \mathrm{KOH}(\mathrm{al}), 80^{\circ} \mathrm{C}, 2.5 \mathrm{~h}\end{array}$ & $\begin{array}{l}\text { 2\% solids, black } \\
105 \min \left(1^{\text {st }}\right), 52 \mathrm{~s}\left(2^{\text {nd }}\right)\end{array}$ & $\begin{array}{l}\text { temperature trace, } \\
\text { air sparge (Test 20) }\end{array}$ \\
\hline $\begin{array}{l}85^{\circ} \mathrm{C} \\
\mathrm{Al} \text { piecewise addition }\end{array}$ & $\begin{array}{l}\text { overnight @ 92 }{ }^{\circ} \mathrm{C}, \\
\text { fresh caustic @ 92 }{ }^{\circ} \mathrm{C} \\
\text { overnight }\end{array}$ & $\begin{array}{l}0.4-3 \mathrm{wt} \% \text {, brown } \\
\text { 17-80s except for contact } \\
\text { with } 3 \mathrm{M} \mathrm{KOH}\end{array}$ & $\begin{array}{l}\text { temperature trace, } \\
\text { (Test 21) }\end{array}$ \\
\hline $\begin{array}{l}92^{\circ} \mathrm{C} \text {, metered caustic } \\
\text { over } 19-23 \mathrm{~h}\end{array}$ & $\begin{array}{l}\text { fresh caustic 2-4 M @ } \\
92^{\circ} \mathrm{C} \text { overnight, except } \\
\text { one }\end{array}$ & $\begin{array}{l}1^{\text {st }}-16 \mathrm{wt} \% \text { took } 9 \text { min } \\
5 \text { wt\% with } \mathrm{NaOH} \\
\text { contact, } 4-10 \mathrm{~min}\end{array}$ & $\begin{array}{l}\text { temperature trace, filtered } \\
\text { one right away } \\
\text { (Test 22) }\end{array}$ \\
\hline $\begin{array}{l}92^{\circ} \mathrm{C} \text {, metered caustic } \\
\text { over } 6 \mathrm{~h}(\sim \text { half amt } \\
\mathrm{NaOH} \text { added })\end{array}$ & $\begin{array}{l}\text { fresh caustic 2-4 M @ } \\
92^{\circ} \mathrm{C} \text { overnight, except } \\
\text { one }\end{array}$ & $\begin{array}{l}1.7 \text { to } 7 \text { min } \\
17-5 \mathrm{wt} \% \text {, black to light } \\
\text { brown }\end{array}$ & $\begin{array}{l}\text { like Test } 22 \text { but shut off } \\
\text { NaOH early (Test 23) } \\
\text { grab samples }\end{array}$ \\
\hline $\begin{array}{l}92^{\circ} \mathrm{C} \text {, over } 5 \mathrm{~h} \\
\mathrm{Al} \text { piecewise addition }\end{array}$ & $\begin{array}{l}\text { 3M fresh caustic @ 92 } \mathrm{C} \\
\text { overnight }\end{array}$ & $\begin{array}{l}1.1 \mathrm{wt} \% \text {, light brown } \\
5 \mathrm{~min}\end{array}$ & $\begin{array}{l}\text { temperature trace } \\
\text { grab samples (Test 24) }\end{array}$ \\
\hline $\begin{array}{l}92^{\circ} \mathrm{C} \text {, metered caustic } \\
\text { over } 19-23 \mathrm{~h}\end{array}$ & $\begin{array}{l}\text { 3M fresh caustic @ 92 }{ }^{\circ} \mathrm{C} \\
\text { overnight }\end{array}$ & $\begin{array}{l}4 \text { times ppt. } 8 \text { wt. } \% \\
\text { filtration took } \sim 7 \mathrm{~h}\end{array}$ & $\begin{array}{l}4 \text { vessels filtered together } \\
\text { (Test 25) }\end{array}$ \\
\hline $\begin{array}{l}\text { Temperature maintained } \\
\text { at }>91^{\circ} \mathrm{C} \text { by metering } \\
\text { caustic }\end{array}$ & $\begin{array}{l}1 \mathrm{M} \text { caustic at RT } \\
\text { overnight pre-treatment, } \\
90^{\circ} \mathrm{C} \text { overnight post- } \\
\text { treatment }\end{array}$ & 6 min, 5 wt.\% solids & $\begin{array}{l}\text { temperature trace and } \\
\text { grab samples (Test 26) }\end{array}$ \\
\hline $\begin{array}{l}60^{\circ} \mathrm{C}, 1 / 3 \text { caustic to start } \\
\text { metered caustic }\end{array}$ & $\begin{array}{l}\text { rapid temperature } \\
\text { increase to boiling }\end{array}$ & 5 min 50s, 7 wt.\% solids & $\begin{array}{l}\text { temperature trace and } \\
\text { grab samples (Test 27) }\end{array}$ \\
\hline $\begin{array}{l}60^{\circ} \mathrm{C}, 1 / 6 \text { caustic to start } \\
\text { metered caustic }\end{array}$ & overnight at $60^{\circ} \mathrm{C}$ & 5 min, 9 wt.\% solids & $\begin{array}{l}\text { temperature trace and } \\
\text { grab samples (Test 28) }\end{array}$ \\
\hline $\begin{array}{l}20^{\circ} \mathrm{C} \text {, full caustic and } 1 / 3 \\
\text { caustic to start }\end{array}$ & $\begin{array}{l}\text { overnight at } 20^{\circ} \mathrm{C} \text {, } \\
\text { addition of all caustic and } \\
\text { then heating to } 90^{\circ} \mathrm{C} \text {, } \\
\text { incubation with fresh } \\
\text { caustic at } 90^{\circ} \mathrm{C} \text { for a few } \\
\text { hours }\end{array}$ & $\begin{array}{l}3 \text { min } 47 \mathrm{~s}, 2 \mathrm{wt} \% \text { solids } \\
5 \text { min } 23 \mathrm{~s} 4 \mathrm{wt} \% \text { solids } \\
11 \mathrm{~min} 45 \mathrm{~s}, 4 \mathrm{wt} \% \text { solids }\end{array}$ & $\begin{array}{l}\text { temperature traces and } \\
\text { grab samples (Test 29, } \\
\text { 30) } \\
\text { temperatures didn't } \\
\text { exceed }\end{array}$ \\
\hline $\begin{array}{l}\text { comparison of metered, } \\
\text { starting conc + metered } \\
\text { variable } \mathrm{Al}\end{array}$ & $\begin{array}{l}\text { pretreatment at } 35^{\circ} \mathrm{C} \\
\text { metering at } 92^{\circ} \mathrm{C}\end{array}$ & $\begin{array}{l}4-9 w t \% \text { solids } \\
3 \text { min } 38 \text { s to } 12 \text { min } 46 s\end{array}$ & $\begin{array}{l}\text { (Test } 31) \\
\text { temperatures did not go } \\
\text { about } 95^{\circ} \mathrm{C} \mathrm{C}\end{array}$ \\
\hline metered & $\begin{array}{l}2^{\text {nd }} \text { caustic, HPC in one } \\
1,2,3 \mathrm{M} \mathrm{NaOH} \\
\text { overnight incubation }\end{array}$ & & $\begin{array}{l}\text { Test 32, HPC improved } 3 \\
\text { M NaOH }\end{array}$ \\
\hline metered & $\begin{array}{l}2^{\text {nd }} \text { caustic } \\
0.5,1,2,3 \mathrm{M} \mathrm{NaOH} \\
\text { all with } \mathrm{HPC} \text { except } 3 \mathrm{M} \text {, } \\
40 \text { h incubation }\end{array}$ & & $\begin{array}{l}\text { Test } 33 \\
\text { tea-bags } \\
\text { filtration fast }\end{array}$ \\
\hline metered & $\begin{array}{l}\text { no tea-bag } \\
0.5,1,2,3 \mathrm{M} \mathrm{NaOH} \\
40+\mathrm{h} \text { incubation } \\
\end{array}$ & & $\begin{array}{l}\text { Test } 34 \text { HPC deleterious? } \\
3 \mathrm{M} \text { took h }\end{array}$ \\
\hline
\end{tabular}




\begin{tabular}{|c|c|c|c|}
\hline $\begin{array}{l}\text { Dissolution Conditions } \\
\text { unless specified: } \\
3 \mathrm{M} \mathrm{NaOH} \text {, } \\
1.5 \mathrm{M} \mathrm{NaNO}_{3}\end{array}$ & Incubation Conditions & $\begin{array}{l}\text { Solids production and } \\
\text { filtration }\end{array}$ & Observations \\
\hline metered & $\begin{array}{l}\text { short incubation (4h) } \\
0.5,1,2,3 \mathrm{M} \mathrm{NaOH}\end{array}$ & & $\begin{array}{l}\text { Test } 35 \\
0.5 \mathrm{M} \text { fastest }\end{array}$ \\
\hline metered over $20 \mathrm{~h}$ & $\begin{array}{l}\text { variable volumes of } 1 \mathrm{M} \\
\mathrm{NaOH} \text { as } 2^{\text {nd }} \text { contact }\end{array}$ & & Test 36, \\
\hline metered over $20 \mathrm{~h}$ & $\begin{array}{l}1,2 \text { and } 3 \mathrm{M} \mathrm{NaOH} \text { as } 2^{\text {nd }} \\
\text { contact }\end{array}$ & & Test 37, half aluminum \\
\hline metered over 20h & $\begin{array}{l}1 \mathrm{M} \mathrm{NaOH} 2^{\text {nd }} \text { contact } \\
50 \mathrm{~mL} \text { additions }\end{array}$ & & $\begin{array}{l}\text { Test 38, half aluminum } \\
\text { scale up }\end{array}$ \\
\hline metered over 20h & $\begin{array}{l}1 \mathrm{M} \mathrm{NaOH} 2^{\text {nd }} \text { contact } \\
100 \mathrm{~mL} \text { additions }\end{array}$ & & Test 39, scale up, \\
\hline
\end{tabular}

\subsubsection{Metered Addition of $\mathrm{NaOH}$ and Control of Dissolution Rate}

Tests were carried out to establish how the aluminum dissolution rate was affected by pretreatment, $\mathrm{NaOH}$ addition, aluminum addition, and incubation bath temperature. These results can be used for planning of hot cell tests to maintain control of reaction conditions during a) aluminum addition, or b) caustic addition.

The metered addition of $\mathrm{NaOH}$ to a vessel containing aluminum and $\mathrm{NaNO}_{3}$ reagents replicated the procedure undertaken at the hot cells, as closely as possible given differences in geometry and radiological effects. Temperatures were logged (T-SPER Scientific 800008) for the dissolution of 8.5 g of aluminum under standard conditions of $[\mathrm{NaOH}]$ and $\left[\mathrm{NaNO}_{3}\right]$ with the Teflon reaction vessel held at various temperatures, from 20 to $92^{\circ} \mathrm{C}$ in a water bath. $\mathrm{NaOH}$ at $10 \mathrm{M}$ was added over the period of 5 to $23 \mathrm{~h}$, depending on the test. As expected, the temperature was found to increase with the metered addition of $10 \mathrm{M} \mathrm{NaOH}$ as the dissolution reaction is exothermic. The stoichiometric amount needed to complete reaction with the metal occurred several hours before the end of the Test, being about one third of the total added caustic.

In Test \#23, shown in Fig. 4, caustic addition was stopped after addition of the stoichiometric amount and the solution was filtered immediately. The amount of solids was large, $17 \mathrm{wt} . \%$ of the initial charge, suggesting that the dissolution process had been interrupted. The gibbsite solubility corresponding to amount of caustic introduced into the reaction vessel is shown on the graph as a dashed line. The curve was calculated using Pitzer-model ${ }^{[36]}$ coefficients provided by Li and coworkers $^{[12]}$ and the mixing coefficients of Wesolowski ${ }^{[9]}$. As can be seen on the graph, the amount of aluminum in solution was greater than that predicted by the equilibrium model, suggesting that gibbsite formation is slower than the dissolution process. Aluminum solubility greater than the gibbsite prediction has been observed in Hanford tank waste and was attributed to the change in the activity of water arising from the ionic strength of the solution. ${ }^{[4]}$ The Hanford chemical system is quite different but does include free hydroxide up to $5.5 \mathrm{M}^{[33]}$ Changes in the hydrogen bonding structure of water in concentrated sodium aluminate solutions may explain this phenomenon. ${ }^{[37]}$ 


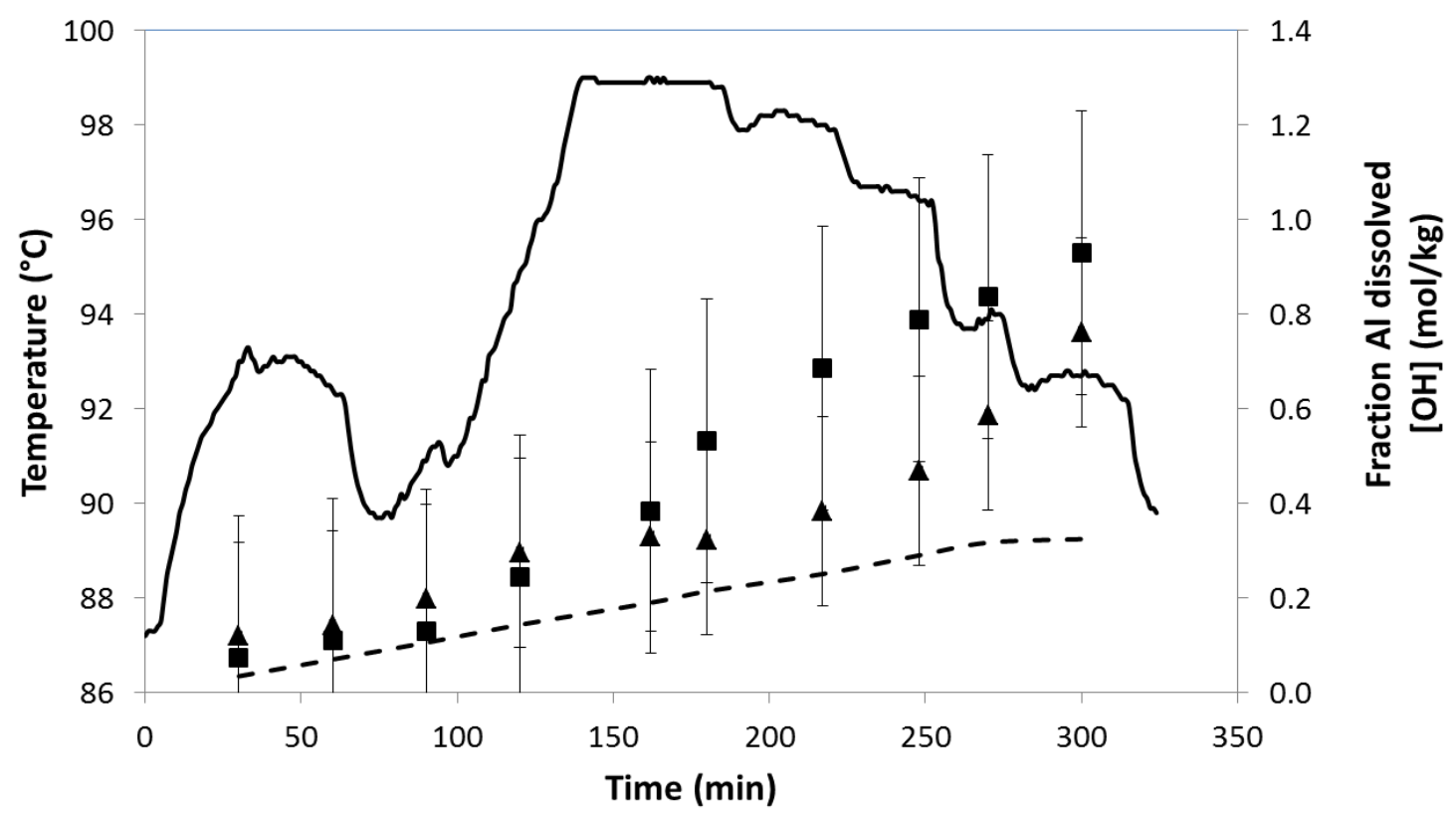

- Temperature

- fraction Al dissolved

\ $[\mathrm{OH}]$ free $\quad$ - Gibbsite solubility

Fig. 4. Temperature and titration data for aluminum dissolution at $92^{\circ} \mathrm{C} .{ }^{[3]}$ The predicted solubility of Gibbsite overlays the plot calculated using a solubility product model based on Pitzer coefficients.

Tests were performed with attempted active control of the reaction rate through manipulation of the metering of caustic and bath temperature, Fig. 5-7. In Test 26, a partial dissolution of aluminum in a nitrate/caustic solution was done at room temperature $\left(20^{\circ} \mathrm{C}\right)$, giving a controlled reaction even when the solution was heated and additional caustic was added through metering. Temperatures were not logged continuously during the first overnight period, but the solution had reached $40.7^{\circ} \mathrm{C}$ after 100 min. The following day, temperatures were increased and caustic was added. In this test, little additional reaction beyond the earlier $30-40 \%$ occurred even when the solution was heated to $85^{\circ} \mathrm{C}$, until additional caustic was provided, indicating that the dissolution reaction was starved for caustic up to that point. 


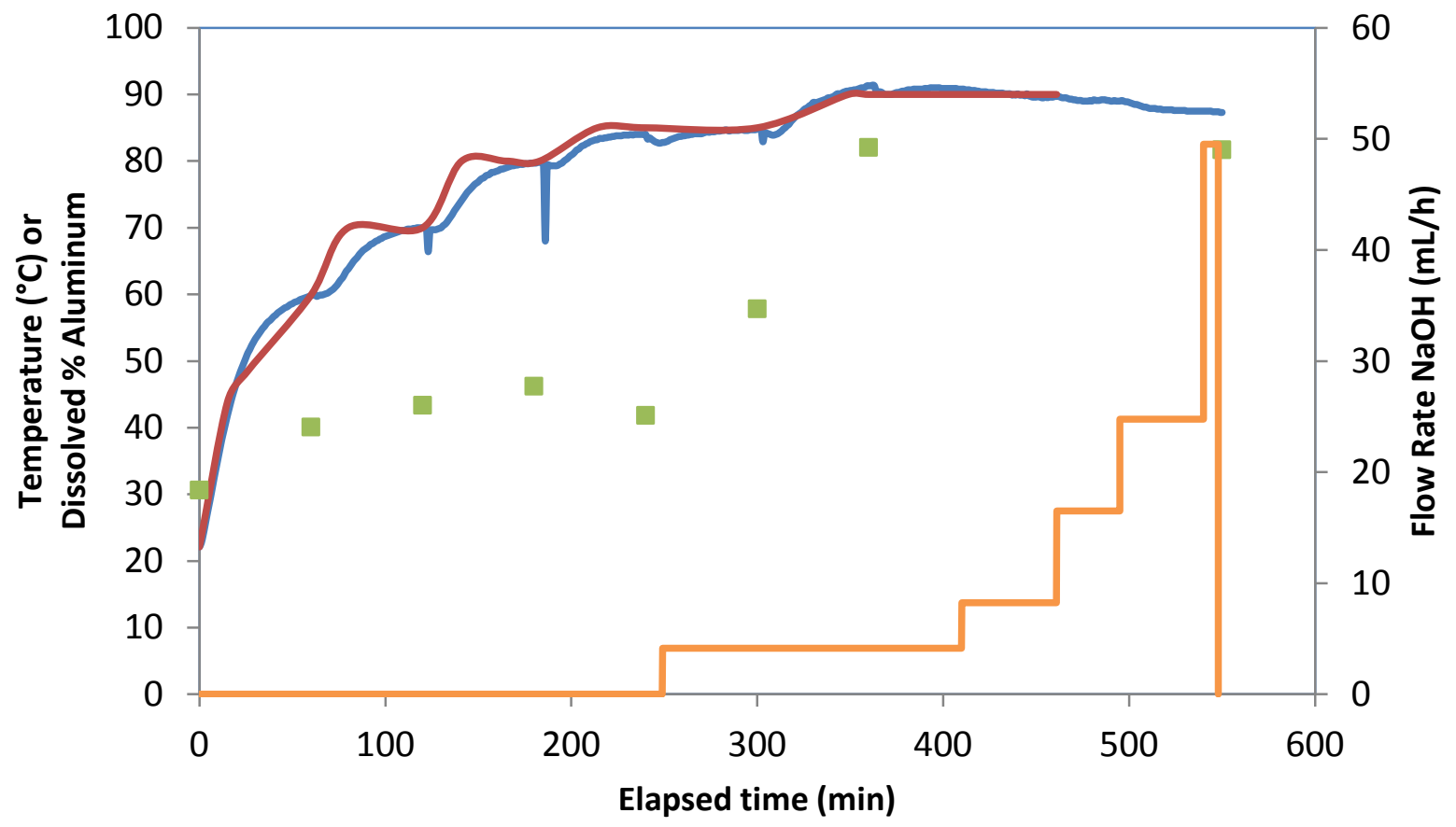

Temperature $\longrightarrow$ Bath Temperature $\square$ Dissolved \% Aluminum $\longrightarrow \mathrm{NaOH}(\mathrm{mL} / \mathrm{h})$

Fig. 5. Temperature, dissolved \% aluminum, and flow rate of caustic as a function of time (Test 26). The reaction vessel data were logged and the aluminum concentrations come from grab samples. Temperatures were not logged during the overnight soak at room temperature, when about $30 \%$ of the aluminum dissolved.

A more aggressive treatment was carried out with the dissolution starting at $60^{\circ} \mathrm{C}$, shown in Fig. 6 . Although only one third of the caustic was provided initially, upon addition of the aluminum the temperature rapidly increased to boiling at $16 \mathrm{~min}$ and remained there for an additional $30 \mathrm{~min}$. Once the reaction stopped and the temperature began to decrease at $45 \mathrm{~min}, \mathrm{NaOH}$ metering began. Stepped increases in $\mathrm{NaOH}$ flow rate and bath temperature did not produce any further excursions in the reaction vessel, suggesting that the rapid kinetics had completed. However, the dissolution of aluminum continued throughout the Test as shown by analyses of the grab samples, also plotted in Fig. 6. 


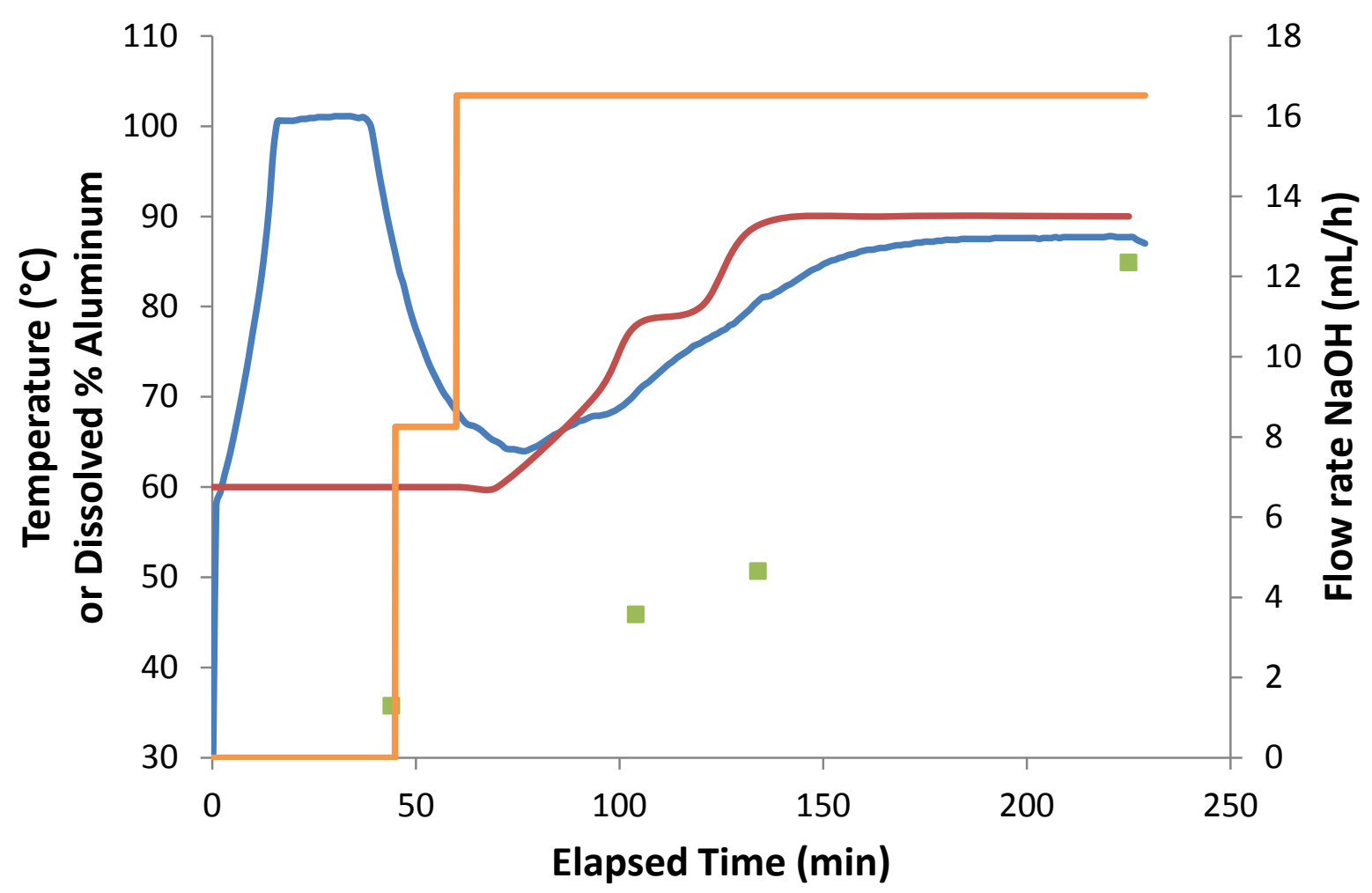

-Temperature Dissolved \% Aluminum $\longrightarrow$ Bath Temperature $\longrightarrow \mathrm{NaOH}(\mathrm{mL} / \mathrm{h})$

Fig. 6. Temperature, dissolved \% aluminum, and caustic flow rate as a function of time (Test 27). The Test started with full nitrate, aluminum and $1 / 3$ of the total caustic were combined at an initial temperature of $60^{\circ} \mathrm{C}$. The reaction vessel data were logged and the aluminum concentrations come from the titration of grab samples.

In Test 28, there was an attempt to actively control the reaction rate through the manipulation of caustic addition and temperature. To prevent the early temperature excursion seen in Test 27, the amount of caustic added at the start of the run was one sixth that of the final amount. However, the aluminum was added all at once as in Test 27 once the bath had reached $60^{\circ} \mathrm{C}$. The temperature in the reaction vessel increased to $70^{\circ} \mathrm{C}$, but the rate of increase was much more moderate than seen in Test 27 and the reaction appeared to come to complete after an hour. Caustic addition was started at a moderate rate, $0.13 \mathrm{~mL} \cdot \mathrm{min}^{-1}$, and combined with gradual bath temperature increases, brought the solution temperature to $84^{\circ} \mathrm{C}$. At $150 \mathrm{~min}$, the caustic addition was increased by a further $50 \%$ to see if the solution could be maintained above $90^{\circ} \mathrm{C}$ as is generally desirable to get a complete reaction. This slight increase, however, was enough to cause the solution temperature to quickly increase beyond $95^{\circ} \mathrm{C}$. The caustic addition was stopped to observe if the rate of reaction would once again decrease, but it did not for over $30 \mathrm{~min}$. Once the temperature started to go down, caustic addition was restarted and eventually ramped up quickly after it did not appear to have much influence on the rate of reaction.

These tests show that the excess of caustic, or lack thereof, strongly influences the rate of reaction. Small changes in the initial amount of caustic in the vessel, and the rate of addition, can starve the reaction, or can cause it to progress very rapidly, Tests 28 and 29 - Figure 7, 8 respectively. In Fig 7, an increase in caustic metering rate at 150 min caused a rapid increase in solution temperature to above boiling. In Fig 8, the run starting with full caustic quickly reached boiling at $95 \mathrm{~min}$, even 
though the addition was done at room temperature. The companion run, starting with only a third of the caustic, had lower aluminum dissolution and lower temperatures. By the end of the test, with all the caustic having been added, the aluminum dissolution was comparable to the rapid dissolution test.
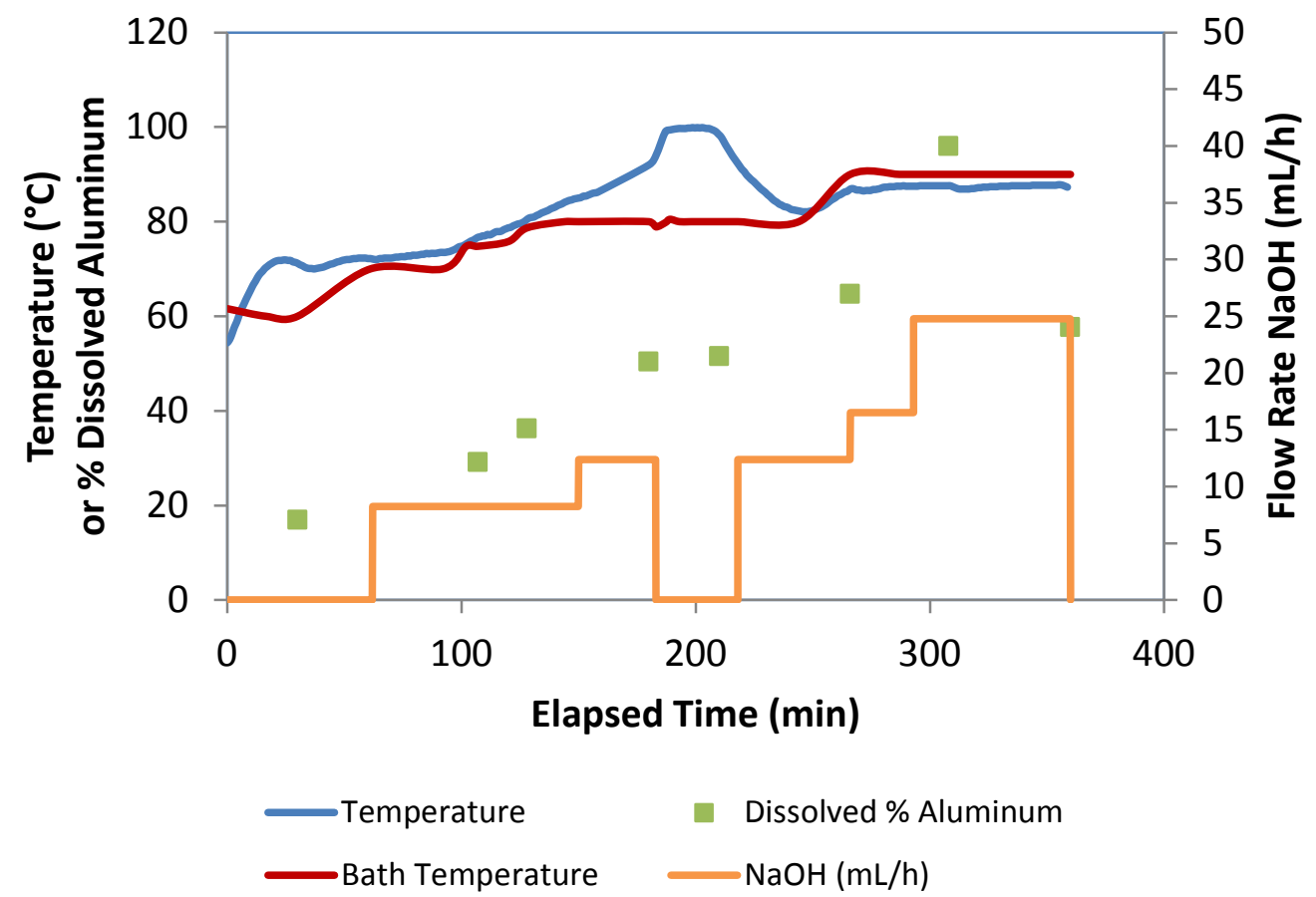

Fig. 7. Temperature, dissolved \% aluminum, and caustic flow rate as a function of time (Test 28). The Test started with full nitrate, aluminum and $1 / 6$ of the total caustic were combined at an initial temperature of $60^{\circ} \mathrm{C}$. The reaction vessel data were and the aluminum concentrations come from grab samples. 

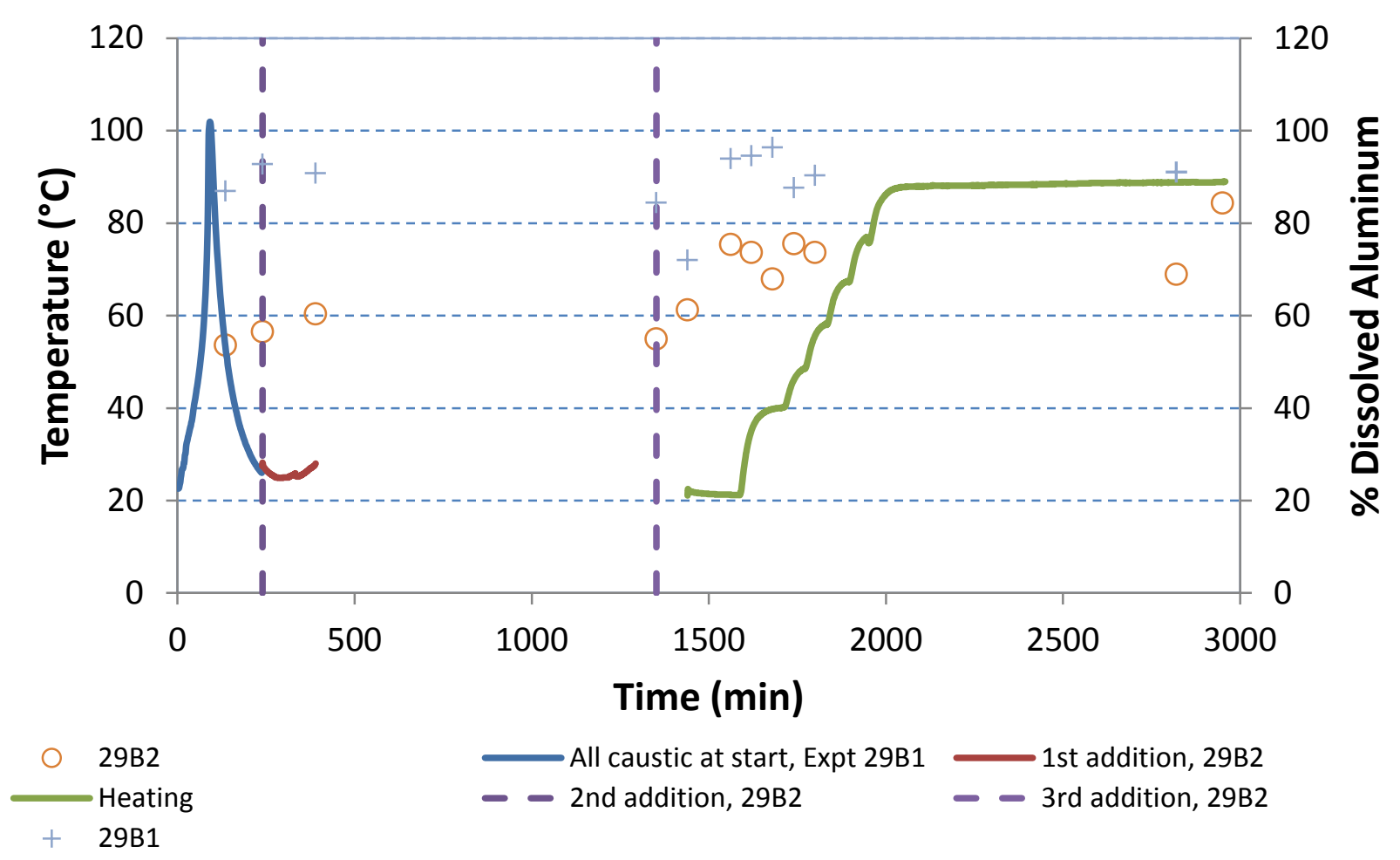

Fig 8. Temperatures (solid lines) and dissolved \% aluminum as functions of time. The tests started out with full caustic (29B1) and 1/3 of the caustic (29B2). Additional caustic to $29 \mathrm{~B} 2$ is shown as the vertical dashed lines. Measured aluminum concentrations are given on the chart.

The masses the solids produced after a second contact with fresh caustic were compared with the recent $20 \mathrm{~h}$ metered Test, as shown in Table 5. As with the earlier Tests, the solids showed a lightening in color during the incubation, suggesting that the iron in the system was dissolving throughout the process. The filtrate also became greenish in color, suggesting that copper was also going into solution as the incubation continued overnight. The tests showed that there was an increase in filtration time with the concentration of caustic in the second incubation period. However, the amount of precipitate in the $20 \mathrm{~h}$ tests was independent of the caustic concentration whereas the amount of precipitate in the $5 \mathrm{~h}$ tests was inversely proportional to the concentration of caustic in the second incubation period. The tests involving metered caustic had more solids than the $1-2 \mathrm{wt} \%$ as observed with the piecewise addition of aluminum. Addition of caustic at $20^{\circ} \mathrm{C}$, either as one addition or as 3 separate additions, did produce low solids, 4 and $2 \mathrm{wt} \%$ respectively after incubation with fresh $3 \mathrm{M} \mathrm{NaOH}$ at $90^{\circ} \mathrm{C}$. The supernatants and filtrates collected following the metered addition were all clear, whereas a fine colloid was formed with the piecewise addition of aluminum that was not captured with the $25 \mu \mathrm{m}$-pore-filter paper. 
Table 5. Results for metered and stepwise $\mathrm{NaOH}$ Tests with varied caustic concentration in the second contact

\begin{tabular}{|c|c|c|c|c|}
\hline 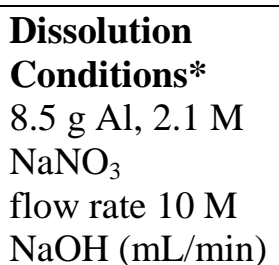 & $\begin{array}{l}\text { Incubation } \\
\text { Conditions* } \\
92^{\circ} \mathrm{C} \text { overnight } \\
{[\mathrm{NaOH}]}\end{array}$ & $\begin{array}{l}\text { g solid } \\
\text { wt.\% of initial } \\
\text { charge of } \mathrm{Al}\end{array}$ & $\begin{array}{l}\text { Color/ } \\
\text { characteristics of } \\
\text { solid }\end{array}$ & $\begin{array}{l}\text { Filtration time } \\
\text { (min) }\end{array}$ \\
\hline 0.066 for $19 \mathrm{~h}$ & not applicable & 1.2266 & \multirow{4}{*}{$\begin{array}{c}\text { dark brown } \\
\text { lighter brown }\end{array}$} & 9.25 \\
\hline 0.052 for $23 \mathrm{~h}$ & $2 \mathrm{M}$ & 0.4406 & & 4.17 \\
\hline 0.056 for $23 \mathrm{~h}$ & $3 \mathrm{M}$ & 0.3939 & & 7.33 \\
\hline 0.054 for $23 \mathrm{~h}$ & $4 \mathrm{M}$ & 0.3990 & & 10.30 \\
\hline 0.1318 for $5.3 \mathrm{~h}$ & not applicable & 1.4413 & $\begin{array}{l}\text { black with } \\
\text { undissolved } \\
\text { material }\end{array}$ & 1.67 \\
\hline 0.1024 for $5.8 \mathrm{~h}$ & $2 \mathrm{M}$ & 0.6325 & \multirow{3}{*}{$\begin{array}{c}\text { dark brown } \\
\text { lighter brown }\end{array}$} & 3.08 \\
\hline 0.1135 for $5.8 \mathrm{~h}$ & $3 \mathrm{M}$ & 0.4739 & & 4.73 \\
\hline 0.1099 for $5.8 \mathrm{~h}$ & $4 \mathrm{M}$ & 0.3939 & & 7.13 \\
\hline $\begin{array}{l}3 \text { additions of } 25 \\
\mathrm{~mL} \text { over } 24 \mathrm{~h}\end{array}$ & $3 \mathrm{M}\left(90^{\circ} \mathrm{C}\right)$ & 0.3497 (4.1 wt\%) & medium brown & 5.38 \\
\hline $\begin{array}{l}1 \text { addition of } 75 \\
\mathrm{~mL} \text { over } 24 \mathrm{~h}\end{array}$ & $3 \mathrm{M}\left(90^{\circ} \mathrm{C}\right)$ & $0.1981(2.3 \mathrm{wt} \%)$ & light brown & 3.78 \\
\hline
\end{tabular}

* Common conditions given in the header.

A second-stage contact in alcoholic $\mathrm{KOH}$ was tested as some literature suggests that this may promote dissolution, ${ }^{[38]}$ but that was not found to be the case here, perhaps because of a blocking mechanism as suggested by Mukherjee and Basumallick.

\subsubsection{Effect of Aluminum Concentration}

A final aluminum concentration of 1.25 $\mathrm{M}$ has become standard in hot cell operation, but the effect of concentration was investigated to see if better dissolution results could be achieved with half, or even less, aluminum in solution. These tests are listed in Table 4, as Tests 11B-2, 11B-3, 12, 14, 15, 16C516C9, and 17 respectively. For most of the tests, there was not a noticeable improvement in the amounts of solids produced relative to the full concentration of aluminum as shown in Fig. 9. For instance the benchmark conditions of a $17 \pm 2 \mathrm{~h}$ dissolution time with metered addition of $10 \mathrm{M} \mathrm{NaOH}$ produced 6-11wt.\% solids with half of the aluminum at the start. Tests with $2-10 \%$ of the benchmark amount of aluminum showed 4-5 wt\% solids produced at the end of the test. Very low amounts of solids, $\sim 1 \%$, were achieved with samples that were first exposed to caustic at room temperature followed by incubation at higher temperatures with fresh caustic. However, in this latter test, the initial amount of aluminum did not correlate with the amounts of solids produced. Overall, these results with differing amounts of aluminum indicated that the aluminum solubility, at least over the relatively short-term conditions of the tests, had not attained thermodynamic equilibrium, in agreement with the results plotted in Fig. 4, and with the literature on sodium aluminate solubility. ${ }^{[39]}$ 


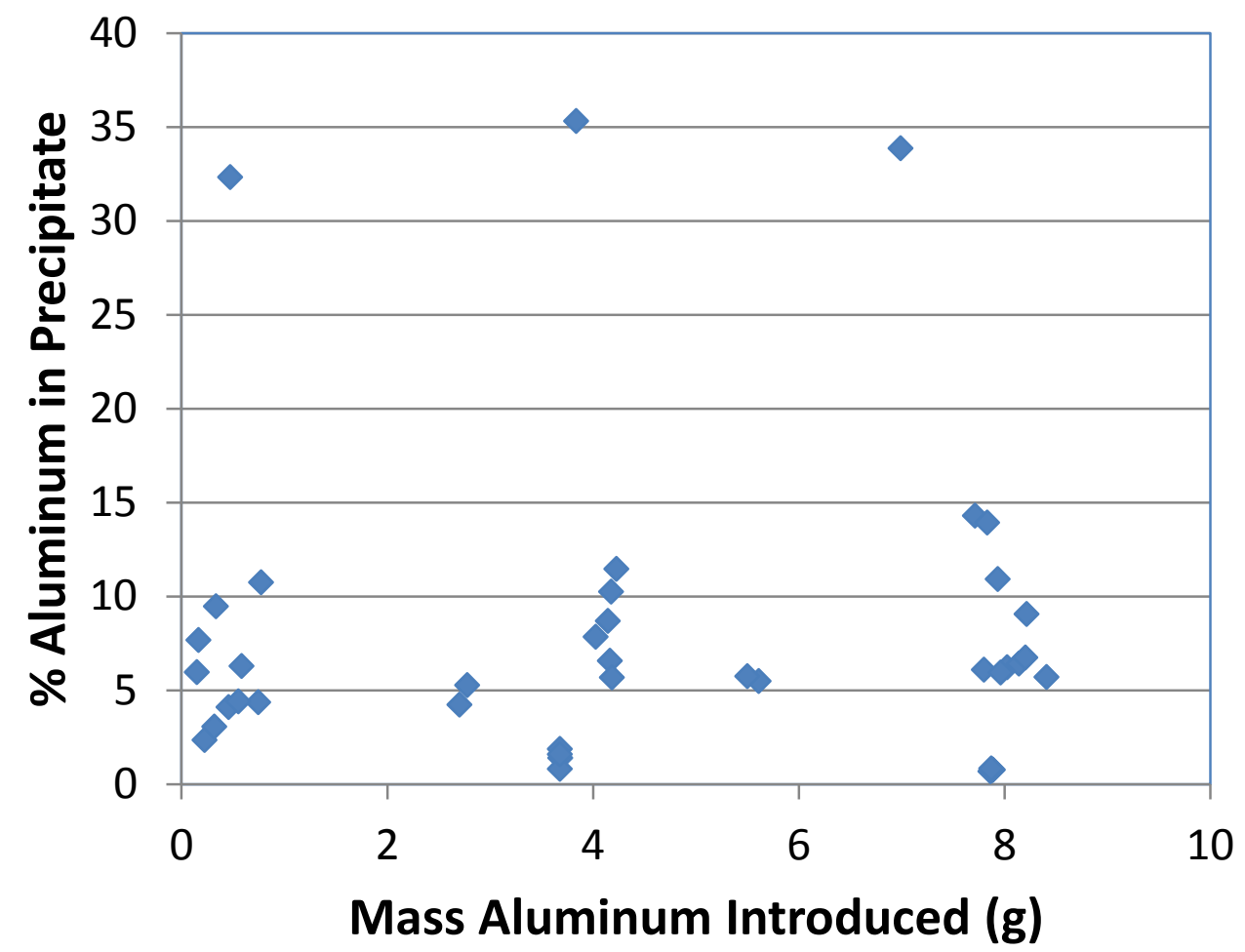

Fig. 9. Percentage of aluminum in the precipitate as a function of the initial amount introduced

Although improvement in aluminum dissolution was not observed when all of the aluminum was added at the beginning of the Test, piecewise addition of aluminum to a solution of $3 \mathrm{M} \mathrm{NaOH}$ and $2.1 \mathrm{M} \mathrm{NaNO}_{3}$ did give improved solubility, Fig. 10. In this test, \#24, 10 pieces of aluminum were added to a mixture of $2.1 \mathrm{M} \mathrm{NaNO}_{3}$ and $3 \mathrm{M} \mathrm{NaOH}$ held at $92^{\circ} \mathrm{C}$ in a water bath. The temperature of the solution was logged during the run, showing a temperature excursion after each addition. The solution did not boil. The maximum temperature reached by the system during the aluminum dissolution was $99^{\circ} \mathrm{C}$, although the bath temperature was held at $92^{\circ} \mathrm{C}$. The aluminum pieces ranged in mass from 0.58 to $1.02 \mathrm{~g}$, with the larger masses being added $5^{\text {th }}$ and $10^{\text {th }}$ respectively. Although most of the pieces were added at 30 min intervals, a full hour was given to allow the $5^{\text {th }}$ piece to dissolve before adding the $6^{\text {th }}$. The solution was maintained at $92^{\circ} \mathrm{C}$ overnight. The following morning, the solution was decanted and recontacted with $3 \mathrm{M}$ caustic. After being held in contact with the fresh caustic for a further $400 \mathrm{~min}$, the solution was filtered. Filtration took almost 5 minutes, but only $1.1 \mathrm{wt} . \%$ solids were produced. 


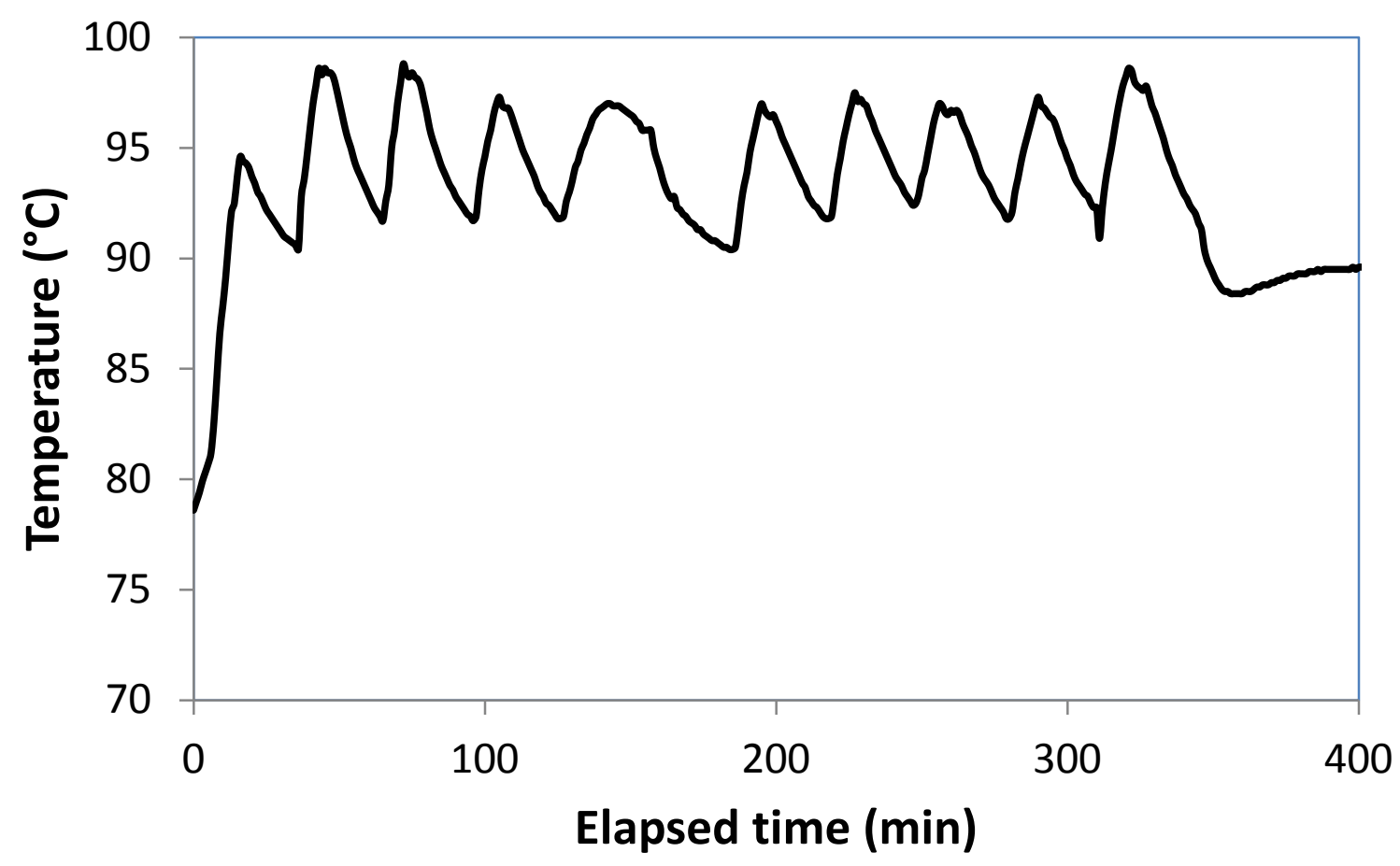

Fig. 10. Temperature versus time for the piecewise dissolution of aluminum. The vessel was held in a $92^{\circ} \mathrm{C}$ waterbath throughout the test.

Titrations of $1 \mathrm{~mL}$ grab samples for the same Test are shown in Fig. 11, with the measured concentration of aluminum tracking closely with the calculated concentration, and a slow decrease in excess hydroxide. Although the grab samples show that the dissolution tracked the addition of aluminum, the last sample taken after dissolution was complete showed a lower concentration of aluminum, thus indicating that the aluminate precipitated upon standing for several days. 


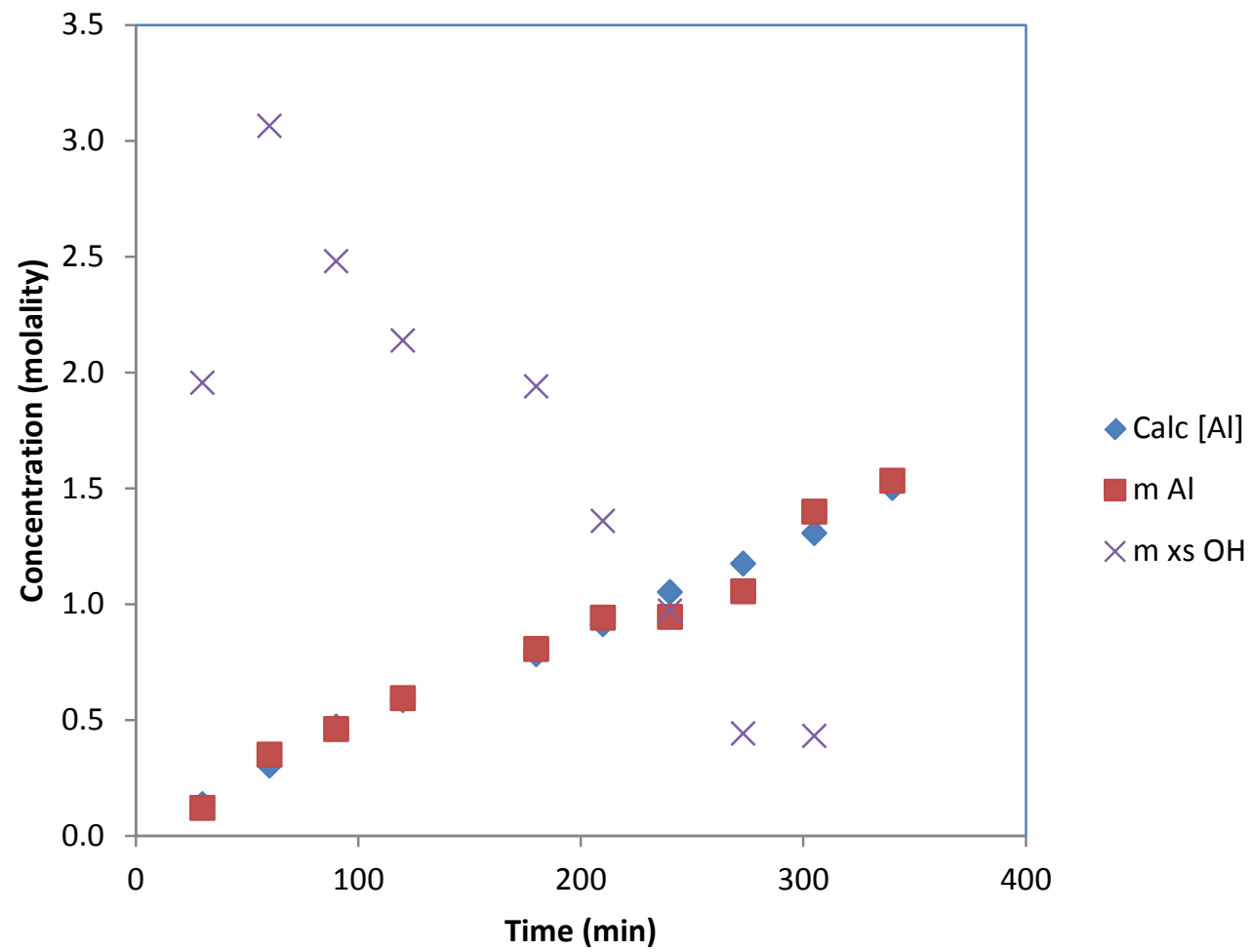

Fig. 11. Titration data from grab samples obtained during a piecewise dissolution of aluminum. ${ }^{[3]}$ The calculated concentration of aluminum (mol $/ \mathrm{kg}$ ) tracks closely with the measured value. The decrease in excess caustic is expected as the amount of aluminum increases. The excess caustic present after the last addition of aluminum was so close to zero that the value was actually calculated to be slightly negative.

\subsubsection{Scaling Dissolution Process to In-cell Size}

While typical concentrations of aluminum, caustic, and nitrate have been used in the dissolution Tests, following guidelines given in the procedure, the scale-up to actual operations is expected to be non-linear. The limitation encountered in batch processing of aluminum targets was attributed to difficulties in filtration of the solids. While the filter medium type, 20-25 $\mu \mathrm{m}$ pore-size filter paper could be reproduced, the size factor between the laboratory $\left(11 \mathrm{~cm}^{2}\right)$ and process scale $\left(360 \mathrm{~cm}^{2}\right)$ surface areas was a factor of 32, representing a factor of 4 in volume of solution from the benchmark laboratory conditions of about $8 \mathrm{~g}$ of aluminum in $250 \mathrm{~mL}$ of solution. Hence, four batches were prepared simultaneously and filtered sequentially to observe effects with scale-up. As can be seen in Fig.12, the filtration time increased exponentially with the first three batches of solution, but then leveled off. When the apparatus was taken apart, the solid precipitate was found to have migrated up the walls of the vessel, making the cake of solid obstructing the flow, to be little changed from batch 3 to batch 4 . This test shows two difficulties involved in scale up; the flow through the filter cake is reduced exponentially with thickness yet larger batches may exhibit flow patterns unique to the geometry of the filtration apparatus. Hence, the focus of the tests has to be reduction in solid rather than reduction in filtration time. 


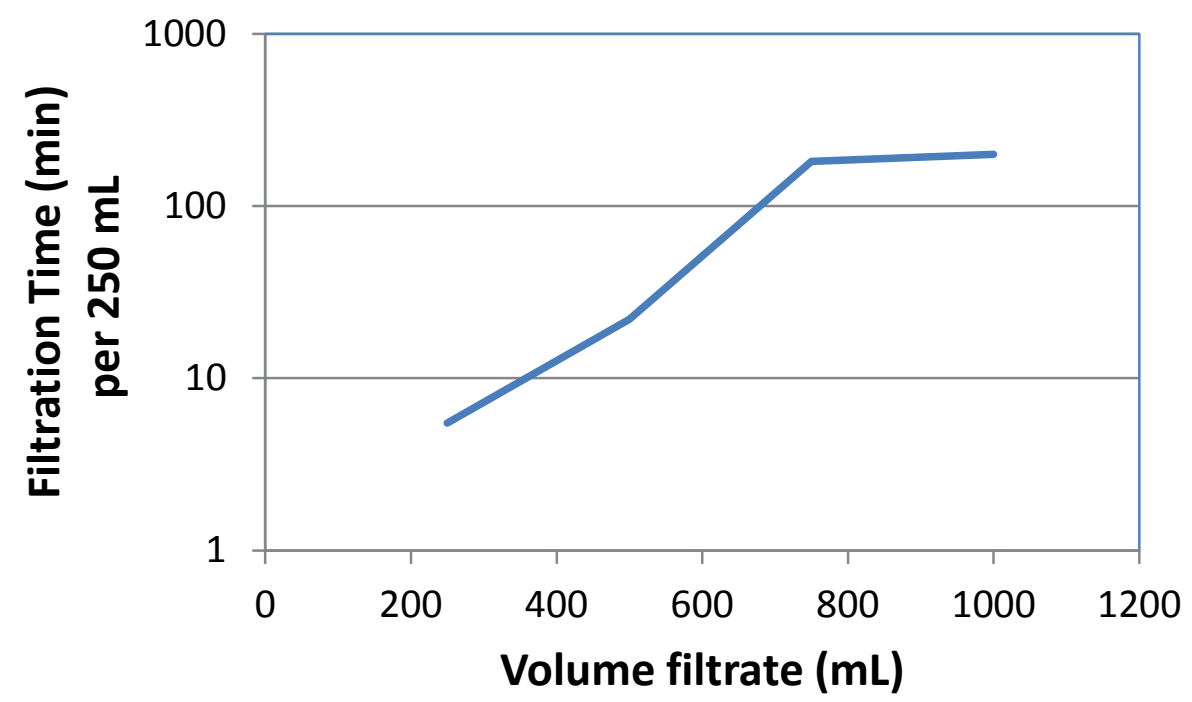

Fig. 12. Filtration time for each of four batches of $250 \mathrm{~mL}$ versus overall volume of filtrate.

\subsection{SUMMARY}

Results of laboratory tests on aluminum dissolution are summarized in Fig. 13, for Tests in which the entire charge of aluminum is in the dissolution vessel at the start of the Test, and caustic is metered into the vessel over an extended period. The graph shows the relative filterability of suspensions that were produced under different dissolution and incubation conditions, plotted as a function of the final aluminum and free hydroxide concentration. Tests with better filterability are plotted with green points, while those that took longer to filter are designated by yellow and red points. The target end point for dissolution operations is denoted by a black square. The two curves are for gibbsite solubility at two temperatures $-60^{\circ} \mathrm{C}$ (red) and $100^{\circ} \mathrm{C}$ (black). These results indicate that filterability of the materials from dissolution of 6061 alloy is variable in the concentration range near the target end point; it appears that the filterability of the solids is a complicated function of time and temperature. This is supported by XRD analyses and visual observations that indicate that the solids undergo phase transformations during the process, and supported by literature observations. ${ }^{[40]}$ More recent Tests at lower aluminum loading have resulted in relatively good filterability.

Based on these results, a set of tests was done where the initial solution contained the full amount of nitrate and caustic, and aluminum was added incrementally, simulating operations in which targets would be introduced in small additions. The green line in the plot indicates the projected course of the aluminum and free hydroxide concentrations during this type of Test, starting from the $\mathrm{x}$-axis (the previous set of Tests started at the origin). The intent of these Tests was to test whether it is possible to mitigate solids formation by starting from below the solubility curve, and indeed, precipitate formation was reduced in these tests, to between 1 and 2 wt.\%. 


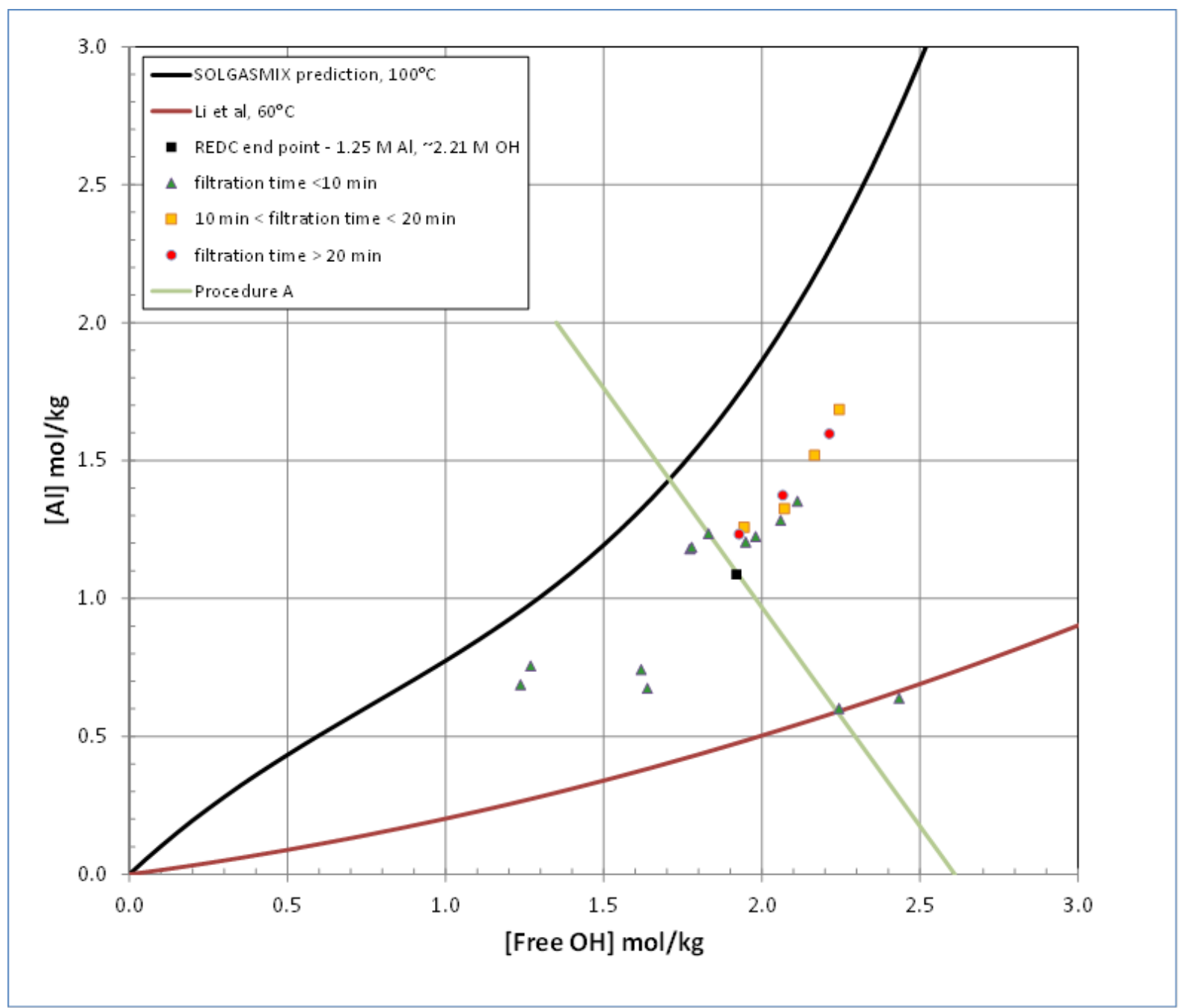

Fig. 13. Solubility of aluminum as a function of hydroxide concentration. Test data are shown as points on the graph. 


\section{CONCLUSIONS}

The goal of these tests was to achieve effective separation of aluminum from target actinide by the dissolution of aluminum. While the solubility of aluminum is high, solid concentrations of up to $10 \%$ can be generated if process variables are not optimized. However, dissolution/filtration has been chosen as the means to achieve separation because of the simplicity and robustness of the unit operations in comparison with other methods ${ }^{[41]}$. In these Tests, it is apparent that the initial dissolution of aluminum produces a solution that is supersaturated compared with respect to thermodynamic predictions of Gibbsite solubility. Long incubation periods, rather than being beneficial, allow the solution to come to equilibrium by allowing the alumino-silicate compounds to nucleate and precipitate.

Assuming that the aluminosilicate precipitate has a very simple form such as mullite, $2 \mathrm{Al}_{2} \mathrm{O}_{3} \cdot \mathrm{SiO}_{2}$, and that all of the silicon had precipitated, one would expect form $6 \pm 2 \mathrm{wt} . \%$ solids. The tests give a greater range than this, and in XRD and XRF examination of the precipitates, it appears as if the dominant chemical species is not aluminosilicate, but includes other salts. Hence, it may be that the main role of the silicon is to promote the nucleation of precipitates through the formation of aluminosilicate networks. ${ }^{[42]}$

Although these Tests have helped to show how to achieve good aluminum dissolution in the hot cell, they are limited by the fact they have been done (i) on non-radioactive samples; (ii) in small scale operations; and (iii) without the presence of other target materials.

Options to assist the dissolution of aluminum alloy 6061 could be difficult to implement in a hot cell, such as the piecewise addition of targets. Other ideas, such as the use of a second caustic rinse, may be easier to add to the dissolution procedure. The solids from the dissolution were found to be less than 10 microns in diameter, much less than the actinide oxides in the target ( $100-\mu \mathrm{m}$-dia.). Hence, separation of residual aluminum solids may be possible using a 100-200 mesh sieve. 



\section{REFERENCES}

1. Ferguson DE, Brown KB, Wymer RG, et al. (1968) Chemical Technology Division annual progress report. Oak Ridge, TN: Oak Ridge National Laboratory. ORNL-4272.

2. Foster DL (1955) The caustic dissolution of unirradiated uranium-aluminum alloy fuel in a trickle-type dissolver. Oak Ridge, TN Oak Ridge National Laboratory. ORNL 55-11-123.

3. McFarlane J, Benker D, DePaoli DW, et al. (2014) Dissolution and separation of aluminum and aluminosilicates. Separation Science and Technology (submitted).

4. Reynolds JG, Reynolds DA (2009) A modern interpretation of the Barney diagram for aluminum solubility in tank waste - 10075. Waste Management 2010 Symposium. Phoenix, AZ: Washington River Protection Solutions.

5. Sipos P (2009) The structure of Al(III) in strongly alkaline aluminate solutions - A review. $J$ Molecular Liquids 146: 1-14.

6. Reynolds DA, Herting DL (1984) Solubilities of sodium nitrate, sodium nitrite, and sodium aluminate in simulated nuclear waste. Richland, WA: Rockwell International.

7. Reynolds JG (2012) The apparent solubility of Al(III) in Hanford high-level waste. Richland, WA: Washington River Protection Solutions.

8. Reynolds DA (1995) Practical modeling of aluminum species in high-pH waste. Richland, WA: Westinghouse Hanford Company.

9. Wesolowski DJ (1992) Aluminum speciation and equilibria in aqueous solution (I): The solubility of gibbsite in the system $\mathrm{Na}-\mathrm{K}-\mathrm{Cl}-\mathrm{OH}-\mathrm{Al}(\mathrm{OH})_{4}$ from 0 to $100{ }^{\circ} \mathrm{C}$ Geochimica et Cosmochimica Acta 56: 1065-1091.

10. Weber CF (2001) Phase Equilibrium Studies of Savannah River Tanks and Feed Streams for the Salt Waste Processing Facility. Oak Ridge, TN: Oak Ridge National Laboratory. ORNL/TM-2001/109.

11. Weber CF (2001) Thermodynamic modeling of Savannah River evaporators. Oak Ridge, TN: Oak Ridge National Laboratory. ORNL/TM-2001/102.

12. Li X-B, Yan L, Zhou Q-S, et al. (2012) Thermodynamic model for equilibrium solubility of gibbsite in concentrated NaOH solutions. Transactions of Nonferrous Metals Society of China 22: 447-455.

13. Wymer RG, Helton DM, Kibbey AH, et al. (1955) Caustic dissolution: Preliminary studies. Oak Ridge, TN: Oak Ridge National Laboratory.

14. Gong X, Nie Z, Qian M, et al. (2003) Gibbsite to Beohmite transformations in strong caustic and nitrate environments. Ind Eng Chem Res 42: 2163-2170.

15. Ruff TJ, Toghiani RK, Smith LT, et al. (2008) Studies on the Gibbsite to Boehmite transition. Sep Sci Technol 43: 2887-2899.

16. Taylor-Pashow KML, Hobbs DT (2012) Effect of cations on aluminum speciation under alkaline conditions. Aiken, SC: Savannah River National Laboratory.

17. Dash B, Tripathy BC, Bhattacharya IN, et al. (2009) Precipitation of boehmite in sodium aluminate liquor. Hydrometallurgy 95: 297-301.

18. Wang Z, Yang L, Zhang J, et al. (2010) Adjustment on gibbsite and boehmite co-precipitation from supersaturated sodium aluminate solutions. Trans Nonferrous Met Soc China 20: 521527.

19. Dash B, Tripathy BC, Bhattacharya IN, et al. (2007) Effect of temperature and alumina/caustic ratio on precipitation of beohmite in synthetic sodium aluminate liquor. Hydrometallurgy 88: 121-126.

20. (2013) Alloy Center Database. Materials Park, OH: ASM International \& Granata Design.

21. Martin WR, Weir JR (1964) Mechanical properties of X8001 and 6061 aluminum alloys and aluminum-base fuel dispersion at elevated temperatures. Oak Ridge, TN: Oak Ridge National Laboratory. ORNL-3557. 
22. Wilmarth WR, Walker DD, Fink SD (1997) Sodium aluminate formation in Tank 43H simulants. Aiken, SC: Westinghouse Savannah River Company.

23. Wilmarth WR, Mills JT, Dukes VH, et al. (2001) Characterization of surface and variable depth samples form the $3 \mathrm{H}$ evaporator feed $(32 \mathrm{H})$ and drop $(30 \mathrm{H})$ tanks - Re-baseline of silicon concentration and aluminosilicate concentration. Aiken, SC: Westinghouse Savannah River Site.

24. Wilmarth WR, Mills JT (2001) Tank 38H desilication study. Aiken, SC: Westinghouse Savannah River Company.

25. Hay MS, Adu-Wusu K, McCabe DJ (2008) Determination of the fraction of Gibbsite and Boehmite forms of aluminum in Tank $51 \mathrm{H}$ sludge. Aiken, SC: Savannah River National Laboratory.

26. Hu MZ, DePaoli DW, Mattus AJ (2003) Results of deposition scoping tests. Oak Ridge, TN: Oak Ridge National Laboratory. ORNL/TM-2003/005.

27. Walker DD (2002) Stability tests with actual Savannah River site radioactive waste. Aiken, SC: Westinghouse Savannah River Company.

28. Jantzen CM, Laurinat JE, Brown KG (2002) Thermodynamic modeling of the SRS Evaporators: Part I. The 2H and 2F Systems (U). Aiken, SC: Savannah River Technology Center. WSRC-TR-2000-293, Rev.1.

29. Nortier P, Chagnon P, Lewis AE (2011) Modelling the solubility in Bayer liquors: A critical review and new models. Chem Eng Sci 66: 2596-2605.

30. Streicher MA (1949) The dissolution of aluminum in sodium hydroxide solutions. II. $J$ Electrochem Soc 96: 170-194.

31. Koroleva EV, Thompson GE, Hollrigl G, et al. (1999) Surface morphological chnages of aluminum alloys in alkaline solution: effect of second phase material. Corrosion Science 41: 1475-1495.

32. Wannenmacher N, Kimura S, Frederick WJ (2005) Solubility of aluminosilicates in Kraft green and white liquors. Ind Eng Chem Res 44: 9316-9322.

33. Agnew SF, Reynolds JG, Johnston CT (2009) Aluminum solubility model for Hanford tank waste treatment - 9123. Waste Management. Phoenix, AZ.

34. Watts HL, Utley DW (1953) Volumetric analysis of sodium aluminate solutions. Analytical Chemistry 25: 864-867.

35. Reynolds JG, Cooke GA, Herting DL, et al. (2012) Evidence for dawsonite in Hanford highlevel nuclear waste tanks. J Hazardous Mater 209-210: 186-192.

36. Pitzer KS (1991) Activity Coefficients in Electrolyte Solutions. Boca Raton, FL: CRC Press.

37. Radnai T, May PM, Hefter GT, et al. (1998) Structure of aqueous sodium aluminate solutions: A solution X-ray diffraction study. J Phys Chem A 102: 7841-7850.

38. Mukherjee A, Basumallick IN (1996) Complex behaviour of aluminium dissolution in alkaline aqueous 2-propanol solution. Journal of Power Sources 58: 183-187.

39. Königsberger E, Königsberger LC, Ilievski D (2011) The beohmite 'solubility gap'. Hydrometallurgy 110: 33-39.

40. Barcza L, Palfalvi-Rozsahegyi M (1989) The aluminate lye as a system of equilibria. Mater Chem \& Phys 21: 345-356.

41. Bloch R, Finkelstein A, Kedem O, et al. (1967) Metal-ion separation by dialysis through solvent membranes. I\&EC Process Design and Development 6: 231-237.

42. Duxson P, Fernandez-Jimenez A, Provis JL, et al. (2007) Geopolymer technology: the current state of the art. Advances in Geopolymer Science and Technology 42: 2917-2933. 


\section{INTERNAL DISTRIBUTION}

1. D. Benker

2. D.W. DePaoli

3. L.K. Felker

4. C.H. Mattus

5. J. McFarlane
6. R.M. Wham

7. ORNL Office of Technical Information and Classification 